\title{
Short Arbitrage, Return Asymmetry, and the Accrual Anomaly
}

\author{
David Hirshleifer \\ Paul Merage School of Business, University of California at Irvine
}

\author{
Siew Hong Teoh \\ Paul Merage School of Business, University of California at Irvine
}

\author{
Jeff Jiewei Yu \\ Cox School of Business, Southern Methodist University
}

\begin{abstract}
We find a positive association between short selling and accruals during 1988-2009, and that asymmetry between the up- and downsides of the accrual anomaly is stronger when constraints on short arbitrage are more severe (low availability of loanable shares as proxied by institutional holdings). Short arbitrage occurs primarily among firms in the top accrual decile. Asymmetry is present only on NASDAQ. Thus, there is short arbitrage of the accrual anomaly, but short-sale constraints limit its effectiveness. (JEL G14, G11)
\end{abstract}

Recently, market upheavals have renewed the perennial debate between those who view short selling as causing downward price distortion, and those who argue that short selling helps correct overpricing. ${ }^{1}$ Short interest, the amount of short selling in a stock, provides a revealing window into the determinants of arbitrage activity and the extent to which arbitrage succeeds in eliminating mispricing. We test here whether short arbitrageurs respond to firm overvaluation, and whether they succeed in correcting it, by measuring the effect on short selling of a proxy for market misvaluation and accruals, and by testing whether constraints on short arbitrage affect the degree to which mispricing

\footnotetext{
This article was previously entitled "Do Short Sellers Arbitrage Accounting-based Stock Market Anomalies?" We appreciate helpful comments and suggestions from Hemang Desai, Owen Lamont, Scott Richardson, and Yinglei Zhang; participants at the American Finance Association Annual Meeting at Boston, the American Accounting Association Annual Meeting at San Francisco, and the accounting workshop at Southern Methodist University; and especially the editor, Matt Spiegel, and anonymous referees. Send correspondence to Siew Hong Teoh, Paul Merage School of Business, University of California at Irvine, Irvine, CA 92697-3125; telephone: (949) 824-5122. E-mail: steoh@uci.edu.

1 Concerns about manipulation through short selling motivated the U.S. Securities and Exchange Commission to make short selling harder by imposing bans in 2008 and 2009 on certain methods of short selling for a selected list of firms. In an announcement of further curbs on short selling, SEC Chairman Schapiro said, "We also are concerned that excessive downward price pressure on individual securities, accompanied by the fear of unconstrained short selling, can destabilize our markets and undermine investor confidence in our markets" (Wall Street Journal, February 25, 2010). Germany followed suit by banning naked short selling (Wall Street Journal, July 2, 2010).
}

(C) The Author 2011. Published by Oxford University Press on behalf of The Society for Financial Studies. All rights reserved. For Permissions, please e-mail: journals.permissions@oup.com. doi:10.1093/rfs/hhr012

Advance Access publication April 11, 2011 
(and therefore return predictability) exists on the short side of the accrual anomaly relative to its long side.

Accounting adjustments to earnings, as reflected in a firm's operating accruals, are strong negative predictors of future abnormal stock returns (Sloan 1996). ${ }^{2}$ Fama and French (2010) identify the accrual anomaly as among the most pervasive and robust of the well-known financial anomalies. Several authors suggest that the accrual anomaly derives from investor naïveté. Under this hypothesis, high accruals cause overvaluation, and subsequent low abnormal returns when this overvaluation is corrected. Similarly, firms with low accruals are underpriced and earn subsequent positive abnormal returns. Market inefficiency is the predominant interpretation of the accrual anomaly. ${ }^{3}$

Sophisticated investors can profit from the accrual anomaly by taking long positions in underpriced stocks (those with low accruals) and going short in overpriced stocks (those with high accruals). We test whether investors engage in short arbitrage of the accrual anomaly specifically by examining whether the relation between short interest and accruals is positive.

Since it is harder or more costly to sell a stock short than to go long, arbitrageurs can more easily exploit underpricing than overpricing. We therefore use asymmetry in return predictability (defined as a difference in the absolute values of top-decile and bottom-decile returns) as an indicator of the relative effectiveness of short versus long arbitrage. We examine whether proxies for the variations in constraints on short arbitrage contribute to asymmetry in return predictability. If short arbitrage operates effectively, we expect to see a relatively low asymmetry in the magnitude of abnormal returns between the short side of the anomaly (when accruals are high) and the long side of the anomaly (when accruals are low), as compared with a market in which short arbitrage is much more constrained than long arbitrage.

Past literature has provided little evidence that investors use short sales to arbitrage the accrual anomaly. Richardson (2003) reports that short sellers do not seem to arbitrage the overvaluation of firms associated with high operating accruals during the 1990-98 period among U.S. (non-NASDAQ) exchangetraded stocks, and suggests that short sellers may be ignoring valuable information. For a sample of firms that engaged in fraudulent or erroneous reporting leading to restatements during the 1997-2002 period, prior short selling was

2 Operating accruals (Sloan 1996) are negative predictors of future returns, as are various accrual components (e.g., operating, investing, and financing accruals; Richardson, Sloan, Soliman, and Tuna 2005), and more inclusive variables that contain accruals (Fairfield, Whisenant, and Yohn 2003; Hirshleifer, Hou, Teoh, and Zhang 2004).

3 The above-mentioned studies document abnormal returns after controlling for standard benchmarks, which suggests that these effects do not derive from rational risk premia. Hirshleifer, Hou, and Teoh (2011) provide evidence that the accrual anomaly is not captured by a rational multifactor pricing model in which factors are built based upon the return-predicting characteristic (accruals). Furthermore, operating accruals are positively associated with overoptimism in analysts' forecasts of future earnings (Teoh and Wong 2002; Drake and Myers 2011), and auditors also do not make full use of information contained in accruals (Bradshaw, Richardson, and Sloan 2001). Polk and Sapienza (2009) use an accrual-based variable as a proxy for mispricing to test its effects on corporate investment. 
related to accruals (Desai, Krishnamurthy, and Venkataraman 2006). A sample that is post-selected based on later events can provide insight about whether short sellers use accrual information to predict future events, but it does not provide a test of (nor do the authors claim it tests) whether short sellers arbitrage the accrual anomaly.

Our tests differ in several key ways from these past studies on short selling and the accrual anomaly. We systematically examine arbitrage of the accrual anomaly in a general sample rather than a post-selected sample of exceptional firms that had earnings restatements, and we cover a twenty-two-year sample period (1988-2009) instead of six to nine years of the above-mentioned studies. Our sample also includes NASDAQ firms, which likely differ from New York Stock Exchange (NYSE) firms in the costs and risks of short selling and the degree of investor mispricing of accruals, and therefore potential profit opportunities from short arbitrage. ${ }^{4}$ Our longer time period includes not only the great bull market of the 1990s, but such events as the earlier (late-1980s) recession, the high-tech stock market crash of 2000-2002, and the recent credit crisis.

Furthermore, we include a more extensive set of test controls suggested by past literature. This is crucial for testing whether there is short arbitrage of the accrual anomaly, as contrasted with short selling in response to other known determinants of short interest, or short arbitrage against some other anomaly variable, such as book-to-market or momentum, that happens to be correlated with accruals. Recent research suggests a rich array of the determinants of short selling, including size, growth, uncertainty of firm environment, firm complexity, ease of borrowing the stock, and market liquidity. (We describe these determinants in Section 1.) To provide sharper tests of the determinants and effects of short arbitrage, we exploit these variables either as controls or as parameters to vary for comparative statics tests.

Most important, our study differs from the past literature in that we test whether greater ease of undertaking short arbitrage strategies makes it more effective, in the sense of reducing the asymmetry between the upside versus the downside of the accrual anomaly. Extensive controls and good instruments for ease of short arbitrage are crucial to verify whether any measured return asymmetry is caused by constraints on short arbitrage. We consider institutional ownership as an instrument for the amount of loanable shares to proxy for the ease of short arbitrage.

4 NASDAQ firms are generally smaller, informationally more opaque, and more growth oriented; they therefore tend to be harder to value. The spread in accruals between the top and bottom accrual deciles among NASDAQ firms is more than twice as large as among NYSE firms, and the return underperformance among high-accrual (top-decile) NASDAQ firms is more than twice as large as among NYSE firms. Asquith, Pathak, and Ritter (2005) report that short selling predicts negative returns only with equally weighted portfolios. This implies that the effects are strongest for small firms, which suggests that it may be especially informative to investigate short selling and arbitrage using NASDAQ firms. 
In sharp contrast with Richardson (2003), we find strong evidence of short arbitrage of the accrual anomaly. In univariate tests, we find that high-accrual firms have higher short interest. Evidence of short arbitrage activity is mainly confined to the top accruals decile. The effect is stronger among NASDAQ firms, for which the mean short interest in the highest accrual decile is over $40 \%$ higher than the mean short interest of the lowest accrual decile.

In multivariate tests that include appropriate controls, we find a significant positive relationship between accruals and short interest. Furthermore, we document a significant positive interaction effect between accruals and institutional holdings; when shares are easier to borrow, there is more short arbitrage of the accrual anomaly. Short arbitrage of accruals is therefore incremental to short selling that occurs in response to other predictors of abnormal returns (such as book-to-market and momentum), and the accruals variable is incremental to other known determinants of short interest. To further control for firm fixed effects, our analysis of changes in short interest shows that there is a significant increase in short interest when firms move into the top accrual decile relative to the preceding year (even among NYSE firms).

In tests of the effectiveness of short arbitrage in attenuating the short side of the accrual anomaly, we find that abnormal return asymmetry is significantly negatively related to institutional ownership. This suggests that when short arbitrage is more constrained, the short-side anomaly remains stronger than the long side of the anomaly.

There are also much greater hedge returns and asymmetry of returns from the accrual anomaly among NASDAQ than NYSE firms. The greater hedge returns on NASDAQ come mainly from the greater abnormal returns from shorting high-accrual NASDAQ firms (80 basis points per month) than from shorting high-accrual NYSE firms (25 basis points per month). On NASDAQ, accrual-strategy abnormal profits are highly asymmetric, with no significant long-side gains from holding firms in the lowest accrual decile. In contrast, NYSE profits are basically symmetric between the long and short sides. These findings suggest that short arbitrage may be more costly, difficult, or risky among NASDAQ firms (though not necessarily because of the trading venue itself).

There has been other recent research that takes advantage of the information in short interest to provide insight into the arbitrage of accounting-related anomalies. Dechow, Hutton, Meulbroek, and Sloan (2001) provide evidence that short sellers take advantage of overpricing as measured by high fundamental-to-price ratios, such as cash-flow-to-price, earnings-to-price, and book-to-market. They report that firms with large short positions tend to have high institutional ownership, consistent with a greater supply of loanable shares or else with institutions being more willing to sell short.

This article differs from Dechow, Hutton, Meulbroek, and Sloan (2001) in several ways. Our article tests for short arbitrage of the accrual anomaly, which is predominantly viewed in the literature as a market inefficiency. In contrast, 
there is a great deal of controversy over whether the value effect (e.g., the book-to-market anomaly) reflects mispricing or rational risk premia. ${ }^{5}$ So, in our article, it is relatively clear cut that the short interest tests are actually about the arbitrage of mispricing. Our article includes a rich set of further control variables (including book-to-market) suggested by recent literature on short interest and on the predictability of returns, which helps ensure that the shortselling patterns we identify come from short arbitrage of the accrual anomaly rather than an accidental correlation. We go further to identify whether the correlation between the anomaly variable (accruals in our case) with short interest come from a causal relationship, by testing whether the relation is stronger in firms for which it is easier to borrow stock (as proxied by institutional holdings). Finally, we test the effectiveness of short arbitrage by examining how constraints on arbitrage and the intensity of investor misperceptions affect the asymmetry of abnormal returns. To our knowledge, our study is the first to perform such a test. ${ }^{6}$

\section{Information Environment, Investor Misperceptions, and Short-sale Constraints}

Past literature has suggested some determinants of short selling that we use as control variables in our regression of short interest on accruals, or as test variables that proxy for ease of arbitrage in our regressions on the determinants of return asymmetry of the accrual anomaly. These variables may be associated with uncertainty in the information environment, risk of short squeezes, investor misperceptions, and ease of short arbitrage.

Short arbitrage of overpriced stocks can be viewed as a response by sophisticated investors to overoptimistic beliefs of naïve investors. We use the term arbitrage in the broad sense to refer to risky transactions that earn profits on average, rather than strict risk-free arbitrage. For various reasons, short arbitrage is costly. ${ }^{7}$

5 As documented by Fama and French (1993), there is co-movement associated with portfolios formed based upon book-to-market. The three-factor model explains much of the ability of book-to-market to predict the crosssection of returns. This is consistent with a rational factor pricing model, although there has been further debate associated with more stringent tests (Daniel and Titman 1997) and with the attempt to link the book-to-market characteristic to economic fundamentals (Griffin and Lemmon 2002).

6 Cao, Dhaliwal, Kolasinski, and Reed (2007) confirm our finding of short arbitrage of the accrual anomaly in a subsample of firms with data on availability of shares for borrowing from 2004 to 2006 . They also consider short arbitrage of post-earnings announcement drift, but do not consider the relation of return asymmetry to ease of short arbitrage.

7 Consistent with short interest at least to some extent representing sophisticated arbitrage of mispricing, short interest is a negative predictor of subsequent abnormal returns (Asquith, Pathak, and Ritter 2005; Desai, Ramesh, Thiagarajan, and Balachandran 2002; Jones and Lamont 2002; Boehmer, Jones, and Zhang 2008; Diether, Lee, and Werner 2009b; and Diether and Werner 2010). There is evidence that when constraints on short arbitrage are more severe, there is greater stock overpricing and return predictability (Jones and Lamont 2002; Lamont and Thaler 2003; Ofek, Richardson, and Whitelaw 2004; Ali and Trombley 2006; Bris, Goetzmann, and Zhu 2007; Cohen, Diether, and Malloy 2007; and Greenwood 2009). Boehmer, Jordan, and Huszar (2010) document an asymmetry in the relation of short interest with returns, with low short interest (coupled with heavy trading) predicting high returns more strongly than high short interest predicting low returns. This is different from the asymmetry in the accrual anomaly that is our focus. 
In order to sell short, an investor must borrow shares from an investor who owns them and is willing to lend. The short seller typically leaves cash collateral with the lender. In addition to the collateral, equal to $102 \%$ of the market value of the borrowed shares, Federal Reserve Regulation T requires short sellers to post an additional 50\% in margin when the lender is a U.S. broker-dealer. The lender pays the short seller interest, the rebate rate, on the collateral. The spread between the rebate rate and the market interest rate on cash funds, often referred to as the loan fee, is a direct cost to the short seller.

D'Avolio (2002) documents that $9 \%$ of stocks have loan fees above $1 \%$ per annum, among which about $1 \%$ have negative rebate rates. He also finds that the probability of being "special" (stocks with high loan fees) decreases with size and institutional ownership, and disagreement among investors seems to predict specialness.

Under current regulations, lenders maintain the right to recall a loan at any time. The recalled borrower can either "cover" the short by buying back the shares and returning them to the lender, or reestablish the short at a higher loan fee. A "short squeeze" occurs when increasingly optimistic investors compete with recalled borrowers to buy shares being sold by lenders. These involuntary closeouts of short trades just when their expected profits are nominally at their highest are a source of risk for short sellers. D'Avolio (2002) documents that in an average month of his sample, $2 \%$ (61) of the stocks on loan are recalled. Conditional on having been recalled, the mean time before the short can be reestablished with the lender is 23 trading days.

We expect short arbitrage to be more active when there is an ample supply of loanable shares. Several authors document that institutional owners provide the main loan supply of stock, and consequently, the level of institutional ownership is a key proxy for ease of short selling (Asquith, Pathak, and Ritter 2005; Nagel 2005). This variable provides a means of testing how short-selling constraints affect the effectiveness of short arbitrage. A key prediction is that low institutional share ownership should be associated with higher return asymmetry. Liquidity, as proxied inversely by the Amihud (2002) illiquidity measure, should encourage arbitrage activity in general. By reducing the risk of short squeezes, it may encourage short arbitrage, thereby reducing return asymmetry.

It is important to control for uncertainty, since greater investor disagreement about a stock should increase short interest (see, e.g., D'Avolio 2002) regardless of whether there is short arbitrage of the accrual anomaly. We use analyst following, residual standard deviation, and book-to-market (since there is likely to be more disagreement about growth firms than mature firms) and whether the firm is earning negative profits (loss firm) to control for differences in uncertainty and firm complexity, which should affect disagreement and mispricing. Analyst following can also affect the accuracy of market perceptions and susceptibility to investor misperceptions (which can potentially overwhelm the arbitrage capital of investors who are willing to sell short). 
We also use residual standard deviation and leverage as proxies for the risk of arbitrage, which should increase return asymmetry.

We provide some results separated by exchange (NYSE versus NASDAQ) because the constraints, costs, and risks of arbitrage (and especially short arbitrage) are likely to differ between firms listed on these two exchanges. NASDAQ firms have greater volatility, lower liquidity, and lower institutional holdings (and therefore fewer shares available for borrowing), and so are subject to a greater risk of a short squeeze. ${ }^{8}$ The exchange variable also captures differences in firm types and investor bases. NASDAQ firms have lower availability of credible public information, smaller relative holdings by institutional (presumably more sophisticated) investors, possible lower quality of earnings, and greater variability in the accrual variable that drives mispricing. These differences should be reduced, though not necessarily eliminated, by the inclusion of controls.

\section{Sample Characteristics and Variable Measurement}

Data to calculate annual accruals are obtained from COMPUSTAT. Prior research has recommended measuring operating accruals from the Statement of Cash Flows rather than the Balance Sheet (Hribar and Collins 2002). Because our short interest data begin in 1988, we are able to use the Statement of Cash Flows, officially required by the Financial Accounting Standards Board only after 1987, to calculate operating accruals as

\section{Operating Accruals $=($ Earnings $-\mathrm{CFO})$ /Average Total Assets.}

Firms are ranked each period by the trading screen (Operating Accruals) and then assigned in equal numbers into ten accrual portfolios. ${ }^{9}$ The High decile accrual portfolio contains firms with the highest accruals, and the Low portfolio contains firms with the lowest accruals.

Firms in the financial services industries (SIC codes 6000-6999) are excluded because the meaning of accounting accruals is different for these industries. We also limit the sample to only those firms trading on NYSE or NASDAQ, excluding American Depository Receipts (ADRs), because we have short interest data only for these exchanges. ${ }^{10}$

Monthly returns are obtained from CRSP. Since firms have different fiscal year-ends, for our accrual-related return tests, we follow the tradition of anomaly studies and rebalance the accrual portfolios each month to take into consideration the new accruals information available. As a result, for each

8 An opposing effect is that regulatory restrictions on short selling are stricter on NYSE than on NASDAQ (Fishman, Hong, and Kubik 2010). In the absence of controls for firm characteristics, the dominant effect on ease of short selling is likely to come from the large differences between the kinds of firms that trade on the different trading venues (see also note 15). Since controls for firm characteristics are necessarily imperfect, whether important differences remain after such controls is an empirical question.

9 Accrual portfolios are rebalanced each fiscal year, except that for return tests they are rebalanced each month.

10 ADRs are eliminated because some of the short interest positions for these observations in our data file exceeded their total number of shares outstanding in CRSP. 
firm, the annual accruals as of the fiscal year-end (month $t$ ) are matched with monthly returns from month $t+5$ through month $t+16$. The four-month gap allows the customary delay between fiscal year-end and the receipt of the $10-\mathrm{K}$ report containing accruals information by investors. The same timing convention is used for the return asymmetry tests. Consequently, for our accrual-related return tests only, we start with 1,036,370 firm-month return observations on CRSP from June 1988 to December 2009, with available accruals on COMPUSTAT in the previous fiscal year.

We obtain monthly short interest data from NASDAQ and NYSE for the period from June 1988 to December 2009. (NASDAQ indicates that the February and July 1990 data are missing from their database.) NASDAQ defines short selling as the selling of a security that the seller does not own, or any sale which is completed by the delivery of a security borrowed by the seller. Therefore, short sellers assume the risk that they may be forced to buy back the stock at a higher price than the price at which they sold short.

NASDAQ indicates that member firms are required to report their short positions in all accounts in shares, warrants, units, ADRs, and convertible preferred stocks resulting. The short positions reported are as of settlement on the fifteenth of each month, or the preceding business day if the 15th is not a business day. The reports must be filed by the second business day after the reporting settlement date. Since it takes three (or five for earlier periods) business days to settle trades, the short interest number includes short sales that occurred three (or five) business days prior to the 15th. NASDAQ publishes the short interest data on the 8th business day after the reporting settlement date. The short selling data from the NYSE are also as of settlement on the 15 th of the month.

Following Asquith, Pathak, and Ritter (2005), we calculate short interest as the short position in a given month scaled by the number of shares outstanding reported on CRSP. To mitigate the potential concern of overlap-induced autocorrelations in short interest ratios within the same firm-year, for our tests on short interest and accruals, we retain only one observation for each firm-year, and we relate each firm-year accrual observation to the short interest position of the firm in the fifth month after the firm's fiscal year-end. The four-month gap between the fiscal year-end and the short position is to ensure that short sellers have the accounting information available to them in Form 10-K prior to taking short positions. ${ }^{11}$

As a result, our final sample for the tests relating short interest to accruals consists of a maximum total of 91,121 firm-year observations $(62,113$

11 We also calculated short interest in two alternative ways: (1) We used only short positions that exceed a cutoff of $0.5 \%$ of shares outstanding, as in Dechow, Hutton, Meulbroek, and Sloan (2001). Dechow et al. argue that large short positions are more likely to represent a consensus among short sellers that a stock is overpriced based on the trading strategy screen, whereas low short positions may reflect short-selling behavior based on other considerations (e.g., risk hedging). (2) For each firm-fiscal year, we average the monthly short positions from month 5 through 16 after the fiscal year instead of using the month-5 short position only. The results are generally similar and so are not reported. 
NASDAQ, and 29,008 NYSE). The different tests in the article impose further varying restrictions on sample size depending on the control variables used.

Table 1 reports summary statistics for our test variables for the final sample used in tests of the relation between short interest and accruals and for subsamples by exchange. The difference between mean and median for Illiquidity shows high skewness, so our later tests use a log transformation of Illiquidity. The mean (median) short interest (SI) in the full sample is $2.20 \%(0.52 \%)$. The mean (median) level of accruals in the full sample is $-0.07(-0.05)$. The means and medians are similar in magnitude to those reported in prior literature. Short selling of NYSE firms is higher than that of NASDAQ firms by both mean and median measures. The notes to Table 1 give detailed definitions of the remaining control variables.

\section{The Accrual Anomaly: Existence and Asymmetry}

Before testing directly whether short sellers trade to exploit the accrual anomaly, it is important first to verify whether it is present during our sample period. Furthermore, we perform return tests of the efficacy of short arbitrage. If short arbitrage is much less effective than long arbitrage, we expect an asymmetry between the predictability of returns on the long and short sides. In other words, we expect the absolute value of the mean subsequent abnormal returns to be larger for the high accruals portfolio than for the low accruals portfolio.

As discussed in the introduction, past research has shown that greater institutional shareholding encourages short selling, because institutional investors are more likely to lend shares. Greater ease of short arbitrage should, in equilibrium, reduce the return asymmetry associated with an anomaly. To provide a sharper test, we then examine how return asymmetry varies with this proxy for the ease of borrowing shares for short selling.

In Table 2, firms are ranked each month for the full sample, or within an exchange subsample, based upon their operating accruals and then sorted into ten deciles. Equal-weighted monthly abnormal returns in each decile are computed using the characteristic-based portfolio matching procedure used in Daniel, Grinblatt, Titman, and Wermers (1997) to control for size, book-to-market, and twelve-month stock return momentum.

In the Daniel, Grinblatt, Titman, and Wermers (1997) procedure, to form benchmark portfolios all observations are first sorted each month into five size quintiles, then within each size quintile into five book-to-market quintiles, and then within each of these twenty-five groups into quintiles based on the firm's past twelve-month returns, skipping the most recent month. Stocks are weighted equally within each of these 125 groups. The size, book-tomarket, and momentum-hedged return for any stock is the difference between the stock's return and that of the equal-weighted benchmark portfolio to which that stock belongs. All $t$-statistics reported are based on the time series of monthly mean portfolio returns. 
Table 1

\section{Description of sample statistics}

\begin{tabular}{lrcrrrr} 
Variable & \multicolumn{2}{c}{ Full Sample } & \multicolumn{2}{c}{ NYSE Sample } & \multicolumn{2}{c}{ NASDAQ Sample } \\
\hline & Mean & Median & Mean & Median & Mean & Median \\
\cline { 2 - 6 } SI $(\%)$ & 2.20 & 0.52 & 2.64 & 1.12 & $\mathbf{2 . 0 0}$ & $\mathbf{0 . 2 7}$ \\
Accruals & -0.07 & -0.05 & -0.06 & -0.05 & $-\mathbf{0 . 0 8}$ & -0.05 \\
IO & 0.37 & 0.32 & 0.54 & 0.56 & $\mathbf{0 . 2 9}$ & $\mathbf{0 . 2 1}$ \\
Resi_IO & -0.06 & 0.13 & 0.18 & 0.17 & $\mathbf{- 0 . 1 8}$ & $\mathbf{0 . 1 0}$ \\
Illiquidity & 8.66 & 0.09 & 0.56 & 0.01 & $\mathbf{1 2 . 4 5}$ & $\mathbf{0 . 4 0}$ \\
Leverage & 0.23 & 0.19 & 0.30 & 0.28 & $\mathbf{0 . 2 0}$ & $\mathbf{0 . 1 2}$ \\
LossFirm & 0.37 & 0 & 0.18 & 0 & $\mathbf{0 . 4 6}$ & 0 \\
STDRES & 0.04 & 0.03 & 0.02 & 0.02 & $\mathbf{0 . 0 5}$ & $\mathbf{0 . 0 4}$ \\
Size (\$m) & 1,935 & 153 & 4,738 & 951 & $\mathbf{6 2 1}$ & $\mathbf{6 9}$ \\
BTM & 0.62 & 0.47 & 0.57 & 0.49 & $\mathbf{0 . 6 5}$ & $\mathbf{0 . 4 5}$ \\
Momentum & 0.11 & 0.00 & 0.09 & 0.06 & $\mathbf{0 . 1 2}$ & $\mathbf{- 0 . 0 4}$ \\
AF & 6.7 & 4.0 & 9.8 & 8.0 & $\mathbf{4 . 6}$ & $\mathbf{3 . 0}$ \\
\hline Sa & & & & &
\end{tabular}

\begin{tabular}{llll}
\hline Sample size & 91,121 & 29,008 & 62,113
\end{tabular}

Table 1 uses a sample of 91,121 firm-year observations with (1) non-missing accruals for the fiscal year (excluding firms in financial services industries, i.e., those with SIC codes between 6000 and 6999) on COMPUSTAT; (2) shares traded on NYSE or NASDAQ and with non-missing monthly return data on CRSP from June 1988 to December 2009, excluding American Depository Receipts (ADRs). Bolded numbers on the NASDAQ Sample columns denote that their values are statistically different from their counterparts of NYSE sample at $p$-values less than 0.01 based on the Satterthwaite $t$-test of difference in means assuming unequal variance and Wilcoxon rank sum test of difference in medians.

\section{Variable definitions:}

SI denotes short interest ratio, calculated as the short position in the fifth month after the fiscal year-end (as reported on the NASDAQ or NYSE monthly short interest files) divided by the number of shares outstanding on the same date (15th of each month or the previous business day if the 15th is not a business day) as reported on the CRSP daily stock file, then multiplied by 100 to express as a percentage.

Accruals is measured at the fiscal year-end and calculated as the difference between earnings before extraordinary items (data item IB) and cash flows from operations (data item OANCF) as reported on the statement of cash flows in the COMPUSTAT Fundamentals Annual file. This variable is scaled by average total assets.

$I O$ denotes institutional ownership, calculated as the total number of shares held by institutions reported on the Thompson $13 \mathrm{f}$ file divided by the total number of shares outstanding on the CRSP monthly file. We use CRSP cumulative adjustment factors to adjust for confounding corporate events such as stock splits. Since $I O$ is a quarterly measure, we match the most recent $I O$ number to each firm-month observation. So, for observations with a short interest report month $t$, depending on the calendar month, it could be matched with $I O$ as of month $t$, or month $t-1$, or month $t-2$.

Resi_IO denotes residual institutional ownership. Following Nagel (2005), we set $\operatorname{logit}(I O)=\log (I O /(1-I O))$, where values of $I O$ below 0.0001 and above 0.9999 are replaced with 0.0001 and 0.9999 , respectively. We then regress logit $(I O)$ on InSize and squared InSize, where InSize are logarithms of market capitalization in millions of dollars measured as of the $I O$ report month. Regressions are run each quarter, and the residuals from the quarterly regressions are defined as residual institutional ownership.

Illiquidity is the average ratio of the daily absolute return to the dollar trading volume on that day calculated over a one-year window ending one month prior to the month of the reported short interest position.

Leverage is measured at the fiscal year-end and calculated as the ratio of long-term debt (data item DLTT) plus debt in current liabilities (DLC), divided by total assets (AT).

LossFirm is a dummy variable taking the value of 1 if net income (data item NI) is negative, 0 otherwise.

STDRES is the standard deviation of the market model residuals for daily returns over a one-year window ending one month prior to the month of the reported short interest position.

Size is calculated as the number of shares outstanding multiplied by stock price on the CRSP monthly file one month prior to the short interest report month. The unit is millions of dollars.

$B T M$ denotes book-to-market, calculated as the book value of common equity (data item CEQ) divided by market capitalization (data item PRCC_F * data item $\mathrm{CSHO}$ ), all measured at the fiscal year-end.

Momentum is the compounded monthly return for the window $(-12,-2)$ from the short position report month. $A F$ denotes the number of analysts following, as reported on the $\mathrm{I} / \mathrm{B} / \mathrm{E} / \mathrm{S}$ Summary History file. It is measured annually as of the fiscal year-end. 
Table 2

Average monthly abnormal returns for accrual portfolios one year after portfolio formation

\begin{tabular}{|c|c|c|c|}
\hline Accruals Decile & Full Sample & NYSE & NASDAQ \\
\hline \multirow[t]{2}{*}{ Lowest } & 0.0008 & 0.0021 & 0.0003 \\
\hline & $(0.46)$ & $(1.68)$ & $(0.16)$ \\
\hline \multirow[t]{2}{*}{2} & $0.0024 * * *$ & 0.0018 & 0.0019 \\
\hline & $(2.85)$ & $(1.86)$ & (1.94) \\
\hline \multirow[t]{2}{*}{3} & $0.0018^{* * *}$ & 0.0001 & 0.0014 \\
\hline & $(2.87)$ & $(0.13)$ & $(1.67)$ \\
\hline \multirow[t]{2}{*}{4} & 0.0010 & 0.0015 & 0.0010 \\
\hline & (1.59) & $(1.57)$ & $(1.24)$ \\
\hline \multirow[t]{2}{*}{5} & 0.0012 & 0.0006 & 0.0013 \\
\hline & (1.84) & (1.03) & $(1.68)$ \\
\hline \multirow[t]{2}{*}{6} & 0.0010 & 0.0002 & 0.0012 \\
\hline & $(1.31)$ & $(0.28)$ & $(1.39)$ \\
\hline \multirow[t]{2}{*}{7} & 0.0002 & 0.0003 & 0.0003 \\
\hline & $(0.30)$ & $(0.54)$ & $(0.28)$ \\
\hline \multirow[t]{2}{*}{8} & $-0.0018 * * *$ & $-0.0022 * * *$ & 0.0000 \\
\hline & $(-2.80)$ & $(-3.68)$ & $(0.01)$ \\
\hline \multirow{2}{*}{9} & $-0.0017 * * *$ & $-0.0021 * * *$ & $-0.0034 * * *$ \\
\hline & $(-2.40)$ & $(-3.30)$ & $(-3.86)$ \\
\hline \multirow[t]{2}{*}{ Highest } & $-0.0050^{* * *}$ & $-0.0022^{* * *}$ & $-0.0053^{* * *}$ \\
\hline & $(-6.37)$ & $(-2.50)$ & $(-5.79)$ \\
\hline \multirow{6}{*}{$\begin{array}{l}\text { Hedge Return } \\
\left(\mathbf{R}_{\mathbf{L}}-\mathbf{R}_{\mathbf{H}}\right) \\
\text { Abnormal Return Asymmetry I } \\
-\left(\mathbf{R}_{\mathbf{H}}+\mathbf{R}_{\mathbf{L}}\right) \\
\text { Abnormal Return Asymmetry II } \\
-\left(\mathbf{R}_{\mathbf{H}}+\mathbf{R}_{\mathbf{L}}\right) /\left(\left|\mathbf{R}_{\mathbf{H}}\right|+\left|\mathbf{R}_{\mathbf{L}}\right|\right)\end{array}$} & $0.0058 * * *$ & $0.0043^{* * *}$ & $0.0056 * * *$ \\
\hline & $(3.44)$ & $(2.72)$ & (3.04) \\
\hline & $0.0042 * *$ & 0.0001 & $0.0050 * *$ \\
\hline & $(2.11)$ & $(0.04)$ & $(2.30)$ \\
\hline & $0.228 * * *$ & 0.028 & $0.194 * * *$ \\
\hline & $(4.68)$ & $(0.55)$ & (3.97) \\
\hline Average number of stocks per month & 4,001 & 1,303 & 2,698 \\
\hline
\end{tabular}

Table 2 uses a sample of 1,036,370 firm-month return observations on CRSP from June 1988 to December 2009, with available accruals on COMPUSTAT in the previous fiscal year (excluding firms in financial services industries, i.e., those with SIC codes between 6000 and 6999) on COMPUSTAT, and the shares are traded on NYSE or NASDAQ, excluding American Depository Receipts (ADRs).

Firms are first sorted into decile portfolios by their values of accruals at the end of the previous fiscal year (month $t$ ), allowing for a minimum four-month lag between the fiscal year-end and the month of return to make sure the accounting information is publicly available. Since firms have different fiscal year-ends, the accruals decile portfolios are rebalanced each month to take into consideration the new accruals data available. For example, a firm ranked among the highest accruals decile on February 1995 may no longer rank among the highest accruals decile on March 1995 when other firms with March fiscal year-end release higher accruals data. As a result, for each firm, its annual accruals as of month $t$ are matched with one year of CRSP monthly returns data from month $t+5$ to month $t+16$. For example, IBM has a December fiscal year-end, so each firm-month observation for IBM from May 1996 to April 1997 is sorted into decile portfolios of the month based on IBM's accruals as of December 1995. As fiscal year 1996 accounting information becomes publicly available, the observation (IBMMay1997) is sorted into accruals decile portfolios of May 1997 based on IBM's accruals as of December 1996, and so on.

The returns are adjusted for survivorship bias associated with delisting stocks, following the procedure proposed in Shumway (1997) and recently refined by Beaver, McNichols, and Price (2007). The monthly abnormal return for each individual stock is calculated by subtracting the equal-weighted return of a benchmark portfolio matched by size, book-to-market, and momentum from the monthly raw return of the stock. The equal-weighted abnormal return for each portfolio is then averaged across the accruals decile. $R_{L}$ denotes the average abnormal return for the lowest accruals decile, and $R_{H}$ denotes the average abnormal return for the highest accruals decile portfolio.

The time-series averages of the monthly portfolio abnormal returns are reported along with their $t$-statistics over the periods shown. The $t$-statistics reported in parentheses are calculated based on a time series of 259 months (Fama-MacBeth approach). Hedge return and return asymmetry measures are calculated the same way. For example, we first calculate the average value of abnormal return asymmetry II, $-\left(\mathrm{R}_{H}+\mathrm{R}_{L}\right) /\left(\left|\mathrm{R}_{H}\right|+\left|\mathrm{R}_{L}\right|\right)$, by month based on the $R_{H}$ and the $R_{L}$ for that month, so we obtain 259 abnormal return asymmetry II numbers, one for each month in the sample. We then calculate the time-series average of these 259 numbers and perform a $t$-test that the time-series average is different from zero. $* *$ and $* * *$ denote statistical significance at the $5 \%$ and $1 \%$ levels, respectively. 
Table 2 indicates that the hedge returns from taking long positions in lowaccrual firms and a short position in high-accrual firms are substantial and significant in the full sample, and much larger among NASDAQ firms than among NYSE firms. Although the relationship between accruals and returns is not perfectly monotonic, the trend in returns is clearly declining as accruals increase. For the sample period 1988-2009, the monthly return spread between low and high accrual deciles in the full sample is 58 basis points per month $(t=$ 3.44). This is actually stronger than either the spread on the NYSE of 43 basis points per month $(t=2.72)$ or on NASDAQ of 56 basis points per month $(t=$ 3.04). ${ }^{12}$ The mean abnormal hedge returns among NASDAQ firms is more than $30 \%$ larger than the return spread among NYSE firms. The larger NASDAQ return spread may reflect that NASDAQ firms tend to have less sophisticated investor bases, and tend to be costly and risky to arbitrage. ${ }^{13}$

On NASDAQ there are no significant long-side profits from holding the lowest accruals portfolio. The difference in the hedge returns on NASDAQ versus NYSE derives mainly from the much more negative returns earned by NASDAQ firms in the highest accrual decile than NYSE firms in the highest accrual decile. For the entire sample period 1988-2009, a long position in the highest accrual decile among NASDAQ firms on average loses 53 basis points per month $(t=-5.79)$, whereas for NYSE firms the loss is less than half as large, -22 basis points per month $(t=-2.50)$. It is not surprising that abnormal profits from the accrual hedge strategy are larger among NASDAQ firms than among NYSE firms since, as we will see in Section 4.1, the dispersion of accruals is much greater among NASDAQ firms.

The rows labeled Abnormal Return Asymmetry I and II provide absolute and relative measures of the asymmetry in the absolute magnitude of the long- versus the short-side returns of the anomaly. Asymmetry $I$ is unscaled; Asymmetry II scales by a measure of the combined strength of the anomaly. In Asymmetry $I,-\left(R_{H}+R_{L}\right)$ is the mean return on a portfolio that is short on the highest and lowest accrual deciles. A larger absolute value of the abnormal returns of the high portfolio $(\mathrm{H})$ compared with those of the low portfolio (L) will increase $-\left(R_{H}+R_{L}\right)$. Asymmetry II is defined as $-\left(R_{H}+R_{L}\right) /\left(\left|R_{H}\right|+\left|R_{L}\right|\right)$.

The absolute measure of asymmetry (Asymmetry $I$ ) captures constraints on the effectiveness of short arbitrage. For example, compare a scenario in which $R_{H}=-2 \%$ and $R_{L}=+1 \%$ with a scenario in which $R_{H}=-20 \%$ and

12 A pooled hedge return can be stronger than the hedge return in either of its subsamples. For example, this can occur if NYSE firms help the pooled sample achieve high returns in the low accrual decile, whereas NASDAQ firms help the pooled sample achieve low returns in the high accrual decile.

13 See the discussion in note 4. Compared with NYSE firms, Table 1 shows that NASDAQ firms in our sample have smaller market capitalizations and institutional holdings, lower liquidity, and higher residual standard deviation. If there are higher uncertainty, lower investor sophistication, and higher costs of arbitrage, then we expect greater misvaluation among NASDAQ than NYSE firms and stronger return anomalies. Furthermore, if these differences constrain short arbitrage, especially among NASDAQ firms, there could be greater asymmetry between the upside of return anomalies (exploitable by taking long positions) and the downside (exploitable by short selling) among NASDAQ firms. In contrast, as discussed in note 8 , there is reason to think that the exchange mechanism on NASDAQ results in lower costs of short selling. 
$R_{L}=+10 \%$. In relative terms, the asymmetry is the same: $R_{H}$ is twice as large in absolute value as $R_{L}$. However, the second scenario involves an enormously bigger failure of the effectiveness of short arbitrage compared with long arbitrage. Short arbitrage costs need to be very large compared with long arbitrage costs to deter shorting, despite an extra $10 \%$ return. In contrast, the first scenario can be explained by a modest extra barrier to short arbitrage-just enough to offset the benefit of an extra $1 \%$ return.

Using either measure, asymmetry is significant and substantial in the full sample. The absolute asymmetry (Asymmetry $I$ ) is 42 basis points per month $(t$ $=2.11)$; the relative asymmetry (Asymmetry II) of 0.228 is also significant $(t=$ $4.68)$. The negative mean abnormal return of -50 basis points per month in the highest accrual decile is much larger in absolute value than the positive mean return of 8 basis points per month among firms in the lowest accrual decile.

This asymmetry comes mainly from the significant and large asymmetry on NASDAQ: 50 basis points per month $(t=2.30)$ with the absolute measure, and $0.194(t=3.97)$ with the relative measure. In contrast, asymmetry under both measures is near zero and insignificant on NYSE. The negative mean abnormal return of -53 basis points in the highest accrual decile on NASDAQ is much larger in absolute value than the positive mean return of 3 basis points in the lowest accrual decile. These findings give a univariate indication that shortselling constraints make short arbitrage of the accrual anomaly less effective on NASDAQ than on the NYSE.

However, short-sale constraints are not the only possible source of return asymmetry. For example, there could be asymmetry in naïve investors' misperceptions of high- versus low-accrual firms. To identify the source more sharply, we perform a multivariate analysis of the determinants of asymmetry. Table 3 examines the determinants of the abnormal return asymmetry in the accrual anomaly by performing a regression across pairs of firms. Each month, firms are first sorted into decile portfolios according to the value of accruals in the previous fiscal year. We then separately rank the firms within the highest accrual decile (denoted by $H$ ) and the lowest accrual decile (denoted by $L$ ) according to the level of institutional ownership. We then form two-firm portfolios by selecting one firm from the highest accrual decile and the other firm from the lowest accrual decile, matching by their institutional ownership ranks. Each observation of Abnormal Return Asymmetry is defined as the negative of the sum of the monthly abnormal returns of the two firms. ${ }^{14}$ We then examine how this firm-pair return asymmetry is associated with institutional ownership and other possible constraints on short selling.

Our focus on extreme accrual deciles is based on the expectation that if there are fixed costs of engaging in short arbitrage, their effects should be

14 A different possible definition of asymmetry would be the difference in differences between $R_{H}-R_{M}$ (where $R_{M}$ is the return on the middle two deciles) and $R_{M}-R_{L}$. Since $\left(R_{M}-R_{H}\right)-\left(R_{H}-R_{M}\right)=-\left(R_{H}+R_{H}\right)+$ $2 R_{M}$, this definition is very similar to our $-\left(R_{H}+R_{H}\right)$ measure. Since we expect the effect of short selling or short-selling constraints to be primarily on the $\mathrm{H}$ portfolio, the $-\left(R_{H}+R_{H}\right)$ measure seems more parsimonious. 
concentrated in the firms that are the most overvalued. The relationship between institutional ownership (IO) and the ease of short selling is also likely to be nonlinear. Once the number of shares available for borrowing reaches a sufficient level, $I O$ is likely to be less of a binding constraint for short selling. We allow for nonlinearity in Models 2 and 3. In Model 1, a log transformation of $I O$ is used. In Model 2, a dummy variable ( $L o w I O)$ is constructed based upon whether institutional ownership exceeds 5\%. In Model 3, we follow Nagel (2005) and use Residual IO, which purges the effect of size.

Our main tests are in Panel A, which examines abnormal return asymmetry I (absolute return asymmetry). For all three model specifications, low institutional ownership is strongly associated with greater abnormal return asymmetry, after controlling for InSize, Leverage, the Amihud illiquidity measure (InIlliquidity) since liquidity may be related to the ease of short selling, and four measures (or inverse measures) of degree of uncertainty and therefore potential investor disagreement (whether the firm is earning negative profits $[$ LossFirm], firm growth/valuation $[B T M]$, analyst following $[A F]$, and the standard deviation of market model residuals [STDRES]). The results are statistically significant at the $1 \%$ level. For example, in Model 1 the coefficient of $\operatorname{lnIO}$ is -0.0641 ( $t=-4.72)$, and similarly in Model 3, Residual IO has a coefficient of $-0.0600(t=-4.61)$.

As an indication of economic magnitude, Model 2 shows that when institutional ownership falls from above $5 \%$ to below $5 \%$, there is on average a

Table 3

Multivariate analysis of abnormal return asymmetry

Panel A: Abnormal Return Asymmetry I

\begin{tabular}{lccc}
\hline Dependent variable: Abnormal Return Asymmetry $\mathbf{I},-\left(\mathbf{R}_{\mathbf{H}}+\mathbf{R}_{\mathbf{L}}\right)$ & & \\
\hline & Model 1 & Model 2 & Model 3 \\
\cline { 2 - 4 } Institutional Ownership Measure & lnIO & LowIO & Residual IO \\
& $-0.0641^{* * *}$ & $0.0094 * * *$ & $-0.0600^{* * *}$ \\
& $(-4.72)$ & $(2.73)$ & $(-4.61)$ \\
\hline lnIlliquidity & $0.0032^{* * *}$ & $0.0036^{* * *}$ & $0.0032^{* *}$ \\
Leverage & $(2.01)$ & $(2.32)$ & $(2.03)$ \\
& 0.0170 & 0.0160 & 0.0167 \\
LossFirm & $(1.81)$ & $(1.72)$ & $(1.78)$ \\
& 0.0016 & 0.0031 & 0.0018 \\
STDRES & $(0.27)$ & $(0.54)$ & $(0.30)$ \\
& -0.6334 & -0.6276 & -0.6395 \\
InAF & $(-1.60)$ & $(-1.54)$ & $(-1.63)$ \\
& -0.0015 & $-0.0051 * *$ & -0.0021 \\
InSize & $(-0.54)$ & $(-2.00)$ & $(-0.77)$ \\
& 0.0044 & 0.0026 & -0.0017 \\
BTM & $(1.59)$ & $(1.06)$ & $(-0.61)$ \\
& 0.0003 & -0.0001 & 0.0002 \\
Constant & $(0.14)$ & $(-0.07)$ & $(0.10)$ \\
& 0.0273 & 0.0229 & $0.0401 * * *$ \\
$N$ & $(1.94)$ & $(1.70)$ & $(2.75)$ \\
Adjusted $R^{2}$ & 102,552 & 102,552 & 102,552 \\
\hline
\end{tabular}


Table 3

Continued

Panel B: Abnormal Return Asymmetry II

\begin{tabular}{|c|c|c|c|}
\hline \multicolumn{4}{|c|}{ Dependent variable: Abnormal Return Asymmetry II, $-\left(\mathbf{R}_{\mathbf{H}}+\mathbf{R}_{L}\right) /\left(\left|\mathbf{R}_{\mathbf{H}}\right|+\left|\mathbf{R}_{L}\right|\right)$} \\
\hline \multirow[b]{2}{*}{ Institutional Ownership Measure } & Model 1 & Model 2 & Model 3 \\
\hline & $\begin{aligned} & \ln I O \\
&-0.2649 * * * \\
&(-5.55)\end{aligned}$ & $\begin{array}{l}\text { LowIO } \\
0.0336 \text { *** } \\
(3.85)\end{array}$ & $\begin{array}{c}\text { Residual IO } \\
\quad-0.2640^{* * *} \\
(-5.54)\end{array}$ \\
\hline \multirow[t]{2}{*}{ InIlliquidity } & 0.0003 & 0.0026 & 0.0004 \\
\hline & $(0.08)$ & $(0.81)$ & $(0.11)$ \\
\hline Leverage & $\begin{array}{l}0.0617 * * * \\
(2.86)\end{array}$ & $\begin{array}{l}0.0586^{* * * *} \\
(2.62)\end{array}$ & $\begin{array}{l}0.0609 * * * \\
(2.81)\end{array}$ \\
\hline LossFirm & $\begin{array}{l}0.0068 \\
(0.44)\end{array}$ & $\begin{array}{l}0.0146 \\
(1.06)\end{array}$ & $\begin{array}{l}0.0079 \\
(0.52)\end{array}$ \\
\hline STDRES & $\begin{array}{l}0.6465 \\
(1.81)\end{array}$ & $\begin{array}{l}0.6992 \\
(1.91)\end{array}$ & $\begin{array}{l}0.6226 \\
(1.73)\end{array}$ \\
\hline $\ln A F$ & $\begin{array}{l}0.0149 \\
(1.55)\end{array}$ & $\begin{array}{l}-0.0018 \\
(-0.20)\end{array}$ & $\begin{array}{l}0.0141 \\
(1.46)\end{array}$ \\
\hline lnSize & $\begin{array}{l}-0.0092 \\
(-1.14)\end{array}$ & $\begin{array}{l}-0.0168 * * \\
(-2.19)\end{array}$ & $\begin{array}{l}-0.0347 * * * \\
(-3.62)\end{array}$ \\
\hline$B T M$ & $\begin{array}{l}0.0076 \\
(1.47)\end{array}$ & $\begin{array}{l}0.0057 \\
(1.12)\end{array}$ & $\begin{array}{l}0.0073 \\
(1.44)\end{array}$ \\
\hline Constant & $\begin{array}{l}0.1181 * * * \\
(3.23)\end{array}$ & $\begin{array}{l}0.1015^{* * *} \\
(2.88)\end{array}$ & $\begin{array}{l}0.1722 * * * \\
(4.55)\end{array}$ \\
\hline $\bar{N}$ & 102,552 & 102,552 & 102,552 \\
\hline Adjusted $R^{2}$ & 0.019 & 0.017 & 0.019 \\
\hline
\end{tabular}

Each month, firms are first sorted into accruals deciles, then two-firm portfolios are formed by selecting one firm from the highest accruals decile and the other firm from the lowest accruals decile, matching by their relative rank order in institutional ownership within the accruals decile for the month. The cumulative annual abnormal return for each individual stock is calculated by subtracting the equal-weighted return of a benchmark portfolio matched by size, book-to-market, and momentum from the raw return of the stock. Abnormal Return Asymmetry $I$ is measured as $-\left(\mathbf{R}_{\mathbf{H}}+\mathbf{R}_{\mathbf{L}}\right)$, and Abnormal Return Asymmetry II is measured as $-\left(\mathbf{R}_{\mathbf{H}}+\mathbf{R}_{\mathbf{L}}\right) /\left(\left|\mathbf{R}_{\mathbf{H}}\right|+\left|\mathbf{R}_{L}\right|\right)$, where $\mathrm{R}_{\mathrm{H}}$ denotes the abnormal return for the stock from the highest accruals decile, while $\mathrm{R}_{L}$ denotes the abnormal return for the stock from the lowest accruals decile. Each of the independent variables is measured each month as the average value within the two-firm portfolio. For example, BTM is the average book-to-market ratio for the two firm-months in the portfolio; that is, $\left(\mathrm{BTM}_{\mathrm{H}}+\mathrm{BTM}_{\mathrm{L}}\right) / 2$. The main independent variable is institutional ownership, and we use several measures of it. In Model 1, we use a continuous measure, $\ln I O$, defined as the log transformation of the average institutional ownership within the two-firm portfolio. In Model 2, we use a dichotomous measure, LowIO, which takes the value of 1 if the average institutional ownership within the two-firm portfolio is less than 5\%, 0 otherwise. In Model 3, we follow Nagel (2005) and construct a similar residual institutional ownership measure for the two-firm portfolio, Residual IO, defined as the residual in the regression of $\operatorname{lnIO}$ on $\ln$ Size and squared $\ln$ Size, all measured at the two-firm portfolio level. InIlliquidity is the average log-transformed illiquidity within the two-firm portfolio. $\ln A F$ is the average log-transformed AF within the two-firm portfolio. InSize is the average log-transformed size within the two-firm portfolio. By construction, the sample size in Table 3 is about $10 \%$ of that in Table 2 (requiring non-missing values on control variables reduces the sample size by a small amount), because we only use the firm-months in the two extreme deciles to construct the two-firm portfolios. The $t$-statistics reported in brackets are computed based on a time series of 259 months using the Fama-MacBeth (1973) approach with Newey-West adjustment for standard errors. ** and $* * *$ denote statistical significance at the $5 \%$ and $1 \%$ levels, respectively.

$0.94 \%$ per month ( $11.28 \%$ annualized) increase in abnormal return asymmetry. Overall, this evidence indicates that short arbitrage of the accrual anomaly is more limited among firms with low institutional holdings, resulting in a stronger short side of the anomaly, and therefore greater asymmetry.

Liquidity reduces the costs of arbitrage in general, and may improve the effectiveness of short arbitrage more than long arbitrage by reducing the risk of short squeezes. This suggests that greater illiquidity may lead to greater return asymmetry. Consistent with this argument, InIlliquidity (the logarithm of the Amihud illiquidity measure) is significantly negatively associated with return 
asymmetry. For example, in Model 1, the coefficient of InIlliquidity is 0.0032 $(t=2.01)$. The results for Models 2 and 3 are very similar. This evidence suggests that liquidity helps improve the effectiveness of short arbitrage.

Table 3 indicates that the effect of institutional ownership on return asymmetry is more strongly significant than that of illiquidity. This is what one would expect, since the ability to borrow stocks is a sharper proxy than general liquidity for the ease of short selling. For example, in Panel A, Models 1 and 3 , the absolute values of the $t$-statistics for $\ln I O$ are about twice as large as those for InIlliquidity. The difference in significance is, however, more modest in Model 2, where an indicator variable is used for institutional ownership.

It could be argued that rational risk premia are the source of return asymmetry, and that this explains why asymmetry persists in equilibrium. We do not rule out the possibility of such asymmetries in risk premia that are not fully captured by standard expected return benchmarks. However, the effects of institutional ownership and illiquidity on asymmetry show that limits to short arbitrage (limited availability of loanable shares, risk of short squeezes) also affect asymmetry. This suggests that asymmetry is at least in part a consequence of mispricing being arbitraged more effectively on the long side than on the short side.

Residual volatility (STDRES) proxies for the risk of arbitrage, which may differentially affect short arbitrage owing to short squeezes. STDRES also proxies for uncertainty, which may contribute both to disagreement (which promotes short selling) and to stronger investor misperceptions. Firms in which there are strong misperceptions can potentially exhaust the capital available for short arbitrage. Similarly, the book-to-market ratio (BTM), as a measure of growth, proxies for uncertainty and potential disagreement. The coefficients on both STDRES and BTM in all three models are statistically insignificant.

Panel B examines Abnormal Return Asymmetry II (relative return asymmetry). Where Panel A tests for the effectiveness of short arbitrage, Panel B describes how important this effectiveness is relative to the overall size of the anomaly. The results in all three models for the institutional ownership measures InIO, LowIO, and Residual IO are very similar to those in Panel A. The main difference is that in Panel B the InIlliquidity variable is small and insignificant in all three models.

\section{The Relationship Between Short Interest and Accruals: Univariate Tests}

Evidence from short interest provides further insight into the nature of short arbitrage. An anomaly that is strong on the down- as well as the upside should be the target of strong short arbitrage, unless even sophisticated investors have failed to recognize the anomaly, or barriers to borrowing stock in order to sell short are severe. Strong short arbitrage, i.e., a strong relation between the return predictor and short interest, suggests that some investors are highly aware of 
the anomaly and are profiting thereby to the extent that the supply of loanable shares permits.

We first examine short arbitrage of the accrual anomaly (Subsection 4.1). Subsection 4.2 discusses how the availability of loanable shares affects the extent of short arbitrage. Subsection 4.3 examines the relation of changes in accrual to changes in short interest.

\subsection{Short arbitrage of the accrual anomaly}

As discussed in the introduction, for the 1990-98 period past research has not detected a statistically significant univariate correlation among NYSE firms between short interest and the level of operating accruals (Richardson 2003). Given the relatively short time period of this finding, it is important to test this using our 1988 to 2009 sample that includes the stock market and high-tech sector bust as well as the preceding market boom. Table 4, Panel A, reports mean short positions across accrual deciles for the full sample and by exchange from 1988 to 2009.

We focus on the top and bottom extreme accrual deciles because, as discussed earlier, we expect short arbitrage to be concentrated in the most overvalued firms. There is clear indication that investors do engage in short arbitrage of the accrual anomaly. The mean short interest in the highest accrual decile is 2.75 , whereas in the lowest accrual decile mean short interest is 2.21 . The difference of 0.63 is highly significant $(t=6.21)$ and is quantitatively substantial relative to the levels of short interest in the different deciles $(0.63$ is $30 \%$ of 2.12 , the amount of short interest for the lowest accrual decile). In other words, variation in accruals has a substantial effect on mean short interest.

Interestingly, in our sample period, there is some indication that investors do engage in short arbitrage of the accrual anomaly even among NYSE firms. The difference in short interest between the highest and lowest accrual deciles is $0.40(t=1.59){ }^{15}$ The modest degree of statistical significance ( $p$-value $5.6 \%$, one-tailed test) contrasts with the insignificant finding in Richardson (2003), so we performed the test again using quintile rankings for NYSE firms from 1990 to 1998 as in Richardson (2003). In unreported results, the point estimate is consistent with borderline significant short arbitrage of the accrual anomaly $(t=1.61)$. Using decile rankings for the Richardson period improved the statistical significance. ${ }^{16}$

15 Short interest is not monotonic across all accrual deciles. For example, NYSE short interest in the lowest accrual decile of 3.19 is higher than in decile 9 , though the difference is not statistically significant. Note that these are univariate tests, and firms in the lowest accrual decile may have other characteristics that are associated with reasons to short these firms.

16 Richardson's sample also included AMEX firms, but we do not have short interest data for this exchange. Our test design also differs from Richardson's in the following ways: (1) We perform several detailed data-cleaning corrections associated with ticker identifiers from the original NYSE database that allowed us to improve matching with the CRSP database. Richardson's sample has a much higher fraction with no short interest activity (23\%) than our sample $(6.36 \%)$. (2) We matched the timing of the short interest report date with the CRSP date for shares outstanding instead of using end-of-month shares outstanding from CRSP to scale short interest, so we have a more accurate adjustment for stock splits and other confounding capital structure changes. (3) We adjust for delisting bias. 
Table 4

Univariate analysis of short interest ratio across accrual portfolios

Panel A: Mean of annual means of short interest ratio (\%) across accrual deciles

\begin{tabular}{lccccc}
\hline Sorting by accruals & Low & 2 & 9 & High & $\begin{array}{c}\text { High - Low } \\
(t \text {-statistic })\end{array}$ \\
Full sample & 2.12 & 2.23 & 2.30 & 2.75 & $\begin{array}{c}0.63^{* * *} \\
(6.21)\end{array}$ \\
NYSE & 3.19 & 2.63 & 2.71 & 3.59 & 0.40 \\
NASDAQ & 1.82 & 1.97 & 2.21 & 2.48 & $\begin{array}{c}(1.59) \\
0.66^{* * *} \\
(6.38)\end{array}$ \\
\hline
\end{tabular}

Panel B: Mean of annual means of accrual spread across NYSE and NASDAQ

\begin{tabular}{llll}
\hline Sorting by accruals & Low & High & High - Low \\
Full aample & -0.41 & 0.17 & 0.58 \\
NYSE (1) & -0.23 & 0.08 & 0.31 \\
NASDAQ (2) & -0.47 & 0.20 & 0.67 \\
\hline Difference: $(2)-(1)$ & $-0.24 * * *$ & $0.12^{* * * *}$ & $0.36^{* * *}$ \\
$(t$-statistic) & $(-9.13)$ & $(9.08)$ & $(14.06)$ \\
\hline
\end{tabular}

Panel C: Summary of short interest ratio spread (\%), accrual spread and return spread (\%)

\begin{tabular}{lccc}
\hline & Full Sample & NYSE & NASDAQ \\
Return Spread/Accrual Spread & 1.00 & 1.39 & 0.84 \\
SI Spread/Accrual Spread & 1.09 & 1.29 & 0.99
\end{tabular}

Table 4 starts with the same 1,036,370 firm-month observations as in Table 2. To mitigate the potential problem of overlap-induced autocorrelation in short interest ratios within the same firm-year, we retain only one short interest observation to relate to each firm-year accrual observation. So, the final sample has 91,121 firm-year observations. Accordingly, observations are sorted into accruals deciles each year, and the corresponding short interest for the firm-year is measured in the fifth month after the previous fiscal year-end. For example, accruals in the fiscal year ending December 1995 are related to the short interest ratio of May 1996.

Short Interest Ratio (SI) is calculated as the short position in the fifth month after the fiscal year end divided by the number of shares outstanding on the same date (15th of each month or the preceding business day if the 15th is not a business day) as reported on the CRSP daily stock file, then multiplied by 100 to express as a percentage. Return Spread is the hedge return $\mathrm{R}_{\mathrm{L}}-\mathrm{R}_{\mathrm{H}}$ as derived from Table 2, converted to percentage points by multiplying 100 to the original value to facilitate comparison. Accrual Spread is the difference in mean accruals values between the highest and lowest accruals deciles, as in Panel B. SI Spread is the difference in mean short interest ratios between the highest and lowest accruals deciles, as in Panel A.

This table presents the means of the 22 annual means of short interest ratio, accruals, and their differences between the extreme deciles. Accordingly, the $t$-statistics reported are based on the time series of the 22 annual means. $* *$ and $* * *$ denote statistical significance at the $5 \%$ and $1 \%$ levels, respectively.

Panel A also shows that the univariate results for NASDAQ firms are even stronger. The mean short interest in the highest accrual decile is 2.48 , which is over 36\% higher than the mean short interest of the lowest accrual decile, 1.82. Thus, the difference of $0.66(t=6.38)$ is economically substantial. Investors seem to be actively engaged in the arbitrage of overvalued, high-accruals firms through short selling.

Why is there greater short arbitrage of the accrual anomaly on NASDAQ than NYSE? The evidence from Table 2 that the accrual anomaly is much stronger on NASDAQ than on NYSE suggests a simple reason, that misperceptions on the part of naïve investors are stronger across accrual deciles on NASDAQ. Such misperceptions, by increasing mispricing, should increase the incentive of sophisticated investors to engage in arbitrage activity. 
A simple reason for greater misperceptions on NASDAQ across accrual deciles is that accruals have much higher dispersion on NASDAQ than on NYSE. Table 4, Panel B, shows that mean accruals are more than twice as negative for the lowest NASDAQ decile as for the lowest NYSE decile, and 2.3 times larger for the highest NASDAQ decile than for the highest NYSE decile. This results in a significantly larger high-low interdecile spread in accruals on NASDAQ than on NYSE. The high minus low decile spread in mean accruals is more than twice as large on NASDAQ than on NYSE (difference in differences of $0.36, t=14.06$ ).

The higher return spreads on NASDAQ do not imply a greater sensitivity of misvaluation to accruals on NASDAQ than on NYSE. Indeed, Panel C shows that the ratio of the return spread to the accrual spread is considerably higher on NYSE than on NASDAQ. Perhaps the market relies more on earnings in valuing NYSE than NASDAQ firms (which tend to be smaller firms with more volatile earnings and are more often loss firms). This suggests that a given increment to accruals for NASDAQ firms has a smaller effect on investor perceptions.

Panel $\mathrm{C}$ indicates that the sensitivity of short interest to accruals per unit of accrual (SI Spread/Accrual Spread) is actually much greater on NYSE than on NASDAQ. Intuitively, as just discussed, there is more mispricing as measured by subsequent abnormal returns per unit of accruals (Return Spread/Accrual Spread) on NYSE than on NASDAQ.

If there are fixed costs of short arbitrage strategies, such as the costs of identifying appropriate positions to take, then we expect short interest to be concentrated among the most overpriced stocks. Consistent with this, Table 4, Panel A, shows that short interest is substantially concentrated in the top accrual decile (Decile 10). In the full sample and in the exchange subsamples, a fairly large fraction of the high-minus-low difference in short interest would still be present even if we compare Decile 10 with Decile 9 instead of comparing Decile 10 with Decile 1. (For the NYSE subsample, the $10-9$ decile difference is actually larger than the $10-1$ difference.)

\subsection{The effect of institutional holdings on short arbitrage of the accrual anomaly}

As discussed earlier, institutional share ownership is a key indicator of the supply of loanable shares, so we expect greater short arbitrage of the accrual anomaly among firms with high institutional holdings. The multivariate analysis of Section 5 explicitly tests for this possibility. But even without including a full set of controls, we can see this effect.

Table 5, Panel A, shows that among firms in the lowest institutional ownership $(I O)$ decile, the mean difference in short interest between the highest accrual decile portfolio and the other accrual decile portfolio is an insignificant -0.039 , whereas in the highest $I O$ decile the mean difference is a substantial 
Table 5

Two-way sort of short interest ratios on accruals and institutional ownership

Panel A: Two-way sort on accruals and institutional ownership (IO)

\begin{tabular}{|c|c|c|c|}
\hline & $\begin{array}{l}\text { Highest Accruals } \\
\text { Decile Portfolio }\end{array}$ & $\begin{array}{l}\text { Other Accruals } \\
\text { Decile Portfolio }\end{array}$ & $\begin{array}{c}\text { Difference: } \\
\text { Highest - Other }\end{array}$ \\
\hline Lowest $I O$ decile & $0.492 * * *$ & $0.453 * * *$ & $0.039 * * *$ \\
\hline Highest $I O$ decile & $8.490 * * *$ & $5.065 * * *$ & $3.425 * * *$ \\
\hline Difference: High - Low & $7.998 * * *$ & $4.612 * * *$ & $3.386 * * *$ \\
\hline \multicolumn{4}{|c|}{ Panel B: Two-way sort on accruals and residual institutional ownership (Resi_IO) } \\
\hline & $\begin{array}{l}\text { Highest Accruals } \\
\text { Decile Portfolio }\end{array}$ & $\begin{array}{l}\text { Other Accruals } \\
\text { Decile Portfolio }\end{array}$ & $\begin{array}{c}\text { Difference: } \\
\text { Highest - Other }\end{array}$ \\
\hline Lowest Resi_IO decile & $0.880 * * *$ & $0.849 * * *$ & $0.031 * * *$ \\
\hline Highest Resi_IO decile & $5.123 * * *$ & $3.832 * * *$ & $1.291 * * *$ \\
\hline Difference: High - Low & $4.243 * * *$ & $2.983 * * *$ & $1.260 * * *$ \\
\hline
\end{tabular}

Table 5 uses the same sample as in Table 4. Firms are ranked annually and assigned to decile portfolios by Accruals, IO, and Resi_IO (see Table 1 notes for variable definitions), respectively. Satterthwaite $t$-tests of difference in means are performed assuming unequal variance. $* * *$ denotes statistical significance at the $1 \%$ level.

$3.425(p<0.01)$. The difference in differences between the highest and lowest institutional ownership deciles is a large and significant 3.386. Similar results are obtained when the comparison is between the highest and lowest accrual deciles. Panel B shows that the results are very similar using residual institutional ownership (Resi_IO). These findings confirm that institutional share ownership is a measure of ease of short selling, and that greater ease of short selling permits greater short arbitrage of the accrual anomaly.

\subsection{Changes in accruals}

As discussed earlier, short interest is likely to be influenced by variables other than accruals, such as the degree of disagreement and the extent of institutional ownership, both of which are likely to vary across industries. To the extent that these other influences are fixed over time, an analysis in changes can filter out such extraneous effects, potentially reducing the noise of the test. Table 6 provides evidence that increases over time in accruals are associated with increases in short interest.

For the full sample in Panel A, a move into the highest accruals decile versus the preceding year is associated with an average increase in short interest of $0.510(t=9.62)$. It is possible that cross-decile shifts in accruals are associated with shifts in other determinants of short interest. To control for this possibility, we use as a benchmark for comparison the mean change in short interest in response to cross-decile shifts to a higher accrual decile among accruals deciles 1 through 9 (10 being the highest decile). Using this benchmark provides a test of whether short arbitrage is especially concentrated in the top accrual decile. A Satterthwaite two-sample test of mean difference (assuming unequal variance) indicates that a move into the highest accruals decile is associated with a significantly higher short interest increase than in the benchmark case (difference $=0.265, t=4.70$ ). 
Table 6

Changes in short interest in response to changes in the decile rank of accruals

Panel A: Changes in short interest across institutional ownership (IO) deciles

\begin{tabular}{|c|c|c|c|c|c|}
\hline & & Lowest IO & & & Highest IO \\
\hline & Full Sample & Decile & IO Decile 2 & IO Decile 9 & Decile \\
\hline $\begin{array}{l}\text { Move into highest } \\
\text { accruals decile }\end{array}$ & 0.510 & 0.010 & 0.119 & 0.823 & 2.262 \\
\hline $\begin{array}{l}\text { Cross-decile } \\
\text { upward shift within } \\
\text { accruals deciles } 1 \\
\text { through } 9\end{array}$ & 0.245 & -0.007 & 0.065 & 0.370 & 0.953 \\
\hline $\begin{array}{l}\text { Difference } \\
\quad(t \text {-statistic })\end{array}$ & $\begin{array}{l}0.265^{* * * *} \\
(4.70)\end{array}$ & $\begin{array}{r}0.017 \\
(0.26)\end{array}$ & $\begin{array}{c}0.054 \\
(0.86)\end{array}$ & $\begin{array}{l}0.453^{* *} \\
(2.37)\end{array}$ & $\begin{array}{l}1.309^{* * *} \\
(3.50)\end{array}$ \\
\hline Panel B: Changes in sh & interest across & ual institut & ownership $(K$ & IO) deciles & \\
\hline & Full Sample & $\begin{array}{l}\text { Lowest } \\
\text { Resi_IO } \\
\text { Decile }\end{array}$ & $\begin{array}{l}\text { Resi_IO } \\
\text { Decile } 2\end{array}$ & $\begin{array}{l}\text { Resi_IO } \\
\text { Decile } 9\end{array}$ & $\begin{array}{l}\text { Highest } \\
\text { Resi_IO } \\
\text { Decile }\end{array}$ \\
\hline $\begin{array}{l}\text { Move into highest } \\
\text { accruals decile }\end{array}$ & 0.510 & 0.028 & 0.326 & 0.781 & 1.385 \\
\hline $\begin{array}{l}\text { Cross-decile } \\
\text { upward shift within } \\
\text { accruals deciles } 1 \\
\text { through } 9\end{array}$ & 0.245 & 0.152 & 0.162 & 0.230 & 0.823 \\
\hline $\begin{array}{l}\text { Difference } \\
\quad(t \text {-statistic })\end{array}$ & $\begin{array}{l}0.265^{* * * *} \\
(4.70)\end{array}$ & $\begin{array}{l}-0.123 \\
(-1.39)\end{array}$ & $\begin{array}{l}0.164 \\
(1.18)\end{array}$ & $\begin{array}{l}0.551 \text { ** } \\
(2.12)\end{array}$ & $\begin{array}{l}0.562 * * * \\
(2.72)\end{array}$ \\
\hline
\end{tabular}

Change in short interest is calculated as the short interest ratio for the firm-year (measured as of the fifth month after the fiscal year-end) minus the short interest ratio for the same firm a year ago. For example, if the accrual is measured as of December 1995 (fiscal year-end), then the corresponding change in short interest is calculated as the difference between the short interest ratio as of May 1996 and the short interest ratio as of May 1995. Firms are ranked annually and assigned to decile portfolios by Accruals, IO, and Resi_IO, respectively (see Table 1 notes for variable definitions). Decile 10 contains firms with the highest accruals. "Move into highest accruals decile" indicates that the firm's accruals decile rank is 10 in year $t$ and less than 10 in year $t-1$. "Cross-decile upward shift within accruals deciles 1 through 9" indicates that the firm's accruals decile rank in year $t$ is greater than its accruals decile rank in year $t-1$, but remains less than 10 after the cross-decile shift. The full sample has 33,073 firm-year observations that are either in the category "Move into the highest accrual decile" or "Crossdecile upward shifts within accruals deciles 1 through 9." Mean changes in short interest across all firm-year observations are reported. The reported $t$-statistics are calculated based on a Satterthwaite two-sample test of mean differences assuming unequal variance. $* *$ and $* * *$ denote statistical significance at the $5 \%$ and $1 \%$ levels, respectively.

To test for the effects of ease of short selling, we compare the effect of accruals changes in firms with high institutional holdings (easier short selling) and low institutional holdings. As shown in the top row, within the bottom $I O$ decile and in $I O$ decile 2, the effects on short interest of moving into the top accruals decile are small $(-0.010$ and 0.119$)$. In contrast, in the top two $I O$ deciles, moving into the highest accruals decile has a considerably larger effect on changes in short interest by several orders of magnitude. The changes in short interest amounts are $0.823(t=3.49)$ for decile 9 , and $2.262(t=6.25)$ for decile 10. The effect on short interest of a move within accruals deciles 1 through 9 is much smaller, so that the difference in the effect on short interest of a move into the top accruals decile versus the benchmark as reported in the bottom is also a strong and significant $0.453(t=2.37)$ for $I O$ decile 9 , and 


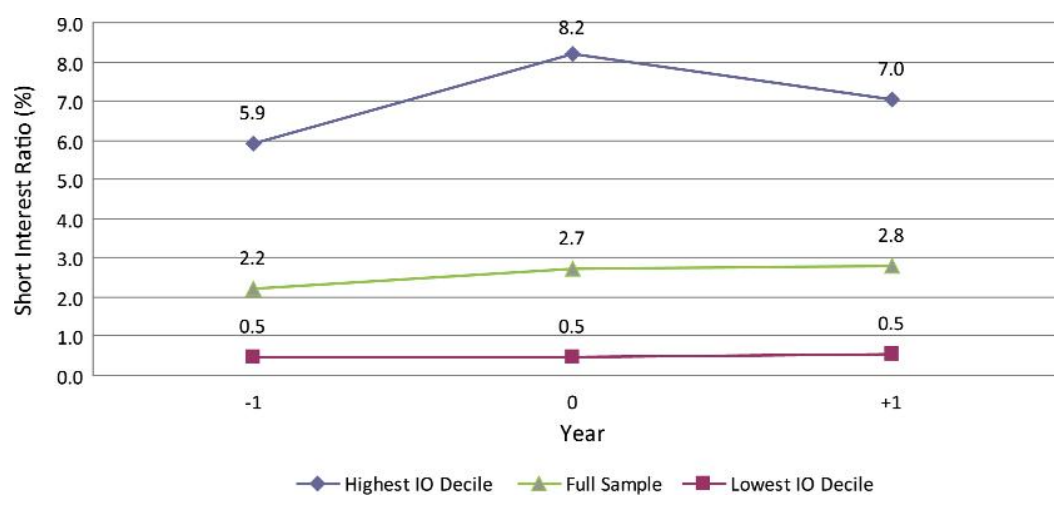

Figure 1

Mean short interest ratio around the time of a move into the highest accruals decile

Firms are ranked annually and assigned to decile portfolios by Accruals and $I O$, respectively. as in Table 4 . However, this figure focuses on 5,044 firm-years that had accruals decile rank less than 10 in year $t-1$, but move into accruals decile 10 (the highest accruals decile) in year $t$.

On the horizontal axis, Year 0 is the event year when firms move into the highest accruals decile. Year -1 $($ Year +1$)$ is one year before (after) the event year. The vertical axis denotes mean short interest ratio (SI) for the corresponding firm-years in percentage points.

We require a four-month gap between the fiscal year-end and the short interest report month to make sure the accounting information is publicly available. See Table 1 notes for the definitions of Accruals, IO, and SI.

$1.309(t=3.50)$ for $I O$ decile 10. Figure 1 illustrates changes of short interest position around the time of a move into the highest accruals decile. Consistent with the findings of Table 6 , on average there is an increase in short interest when the firm-year moves into the highest accruals decile. Among firms with high institutional holdings, we observe notable jumps in short interest from year -1 to year 0 , in contrast to the nearly flat lines for firms with low institutional holdings.

\subsection{The timing of short arbitrage and its reversal}

The annual tests we have considered do not tell us the exact timing of short selling in relation to the arrival of news about accruals. It is useful to explore the timing more finely, since competing scenarios have different implications. Under the scenario that short sellers arbitrage the accrual anomaly, we expect short interest positions to be high when information indicating that accruals are high becomes available, and then to decline over the lifetime of the accrual anomaly. If short arbitrageurs use accruals as a trading screen, they will wait until they possess an accrual number before they take a position on it. An alternative scenario is a bear raid by short arbitrageurs. When this happens, we expect the firm to respond by managing earnings upward to prevent a price fall. Under this scenario, high short selling precedes the disclosure of accruals. This time lag is because accruals are only disclosed several months after the end of the quarter being reported on.

Figure 2 describes the monthly timing of short interest in relation to the months relative to the month of the quarter-4 earnings announcement. Short 


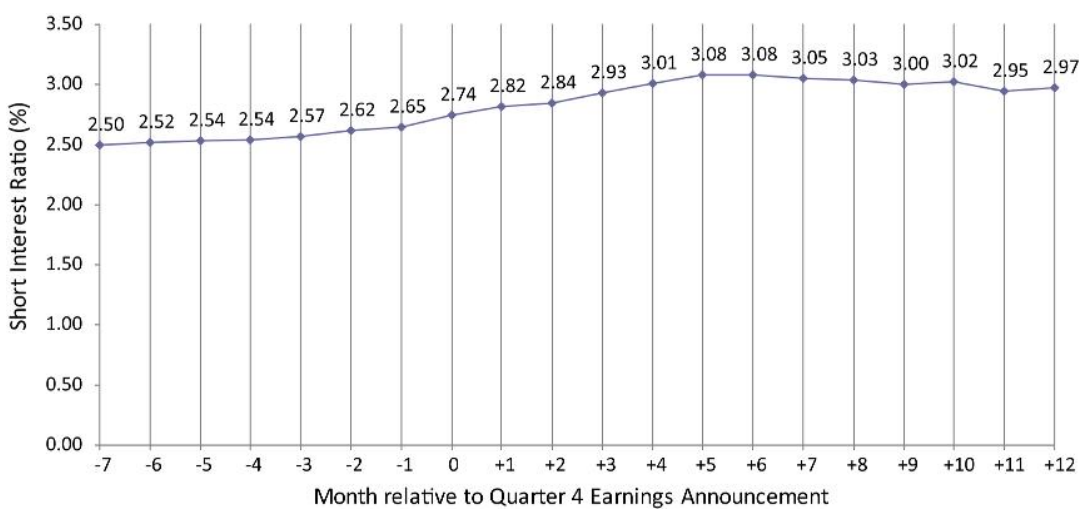

Figure 2

Mean short interest ratio surrounding quarter-4 earnings announcement for firms that move into the highest accruals decile

Firms are ranked annually and assigned to decile portfolios by Accruals as in Table 4. This figure examines 4,671 firm-year observations that (1) had accruals decile rank less than 10 in year $t-1$, and move into accrual decile 10 (the highest accruals decile) in year $t$; (2) have non-missing quarter-4 earnings announcement date on COMPUSTAT. On the horizontal axis, Month 0 (event month) is the month of quarter- 4 earnings announcement, and other months are defined relative to the event month. For the sample, the mean (median) number of months between fiscal year-end and quarter-4 earnings announcement is 2.33 (2.00), with 75th percentile of 3 months. So, fiscal year-end corresponds approximately to month -2 or -3 on the horizontal axis. The vertical axis gives the short interest ratio (SI, measured as of the 15th of each month or the previous business day if the 15th is not a business day) for the corresponding firm-month in percentage points. See Table 1 notes for the definitions of Accruals and SI.

interest rises in month 0 and does not peak until month +5 . This pattern is consistent with short interest positions taken when information about accruals is available at the time that financial statements are released. The pattern is inconsistent with high accruals occurring as a response to an earlier peak in short interest from a bear raid. In other words, the shape of Figure 2 is consistent with the hypothesis that there is short arbitrage of the accrual anomaly.

\subsection{Time trend in accrual anomaly and short arbitrage}

Owing to investor learning and institutional changes, we expect changes over time in the accrual anomaly and arbitrage behavior. Figure 3 describes the time-series evolution of the accrual anomaly and short arbitrage activity across consecutive five-year subperiods from 1990 through 2009. There is a decline in trading profits for the accruals anomaly across subperiods; Figure 3 shows that this is driven by a decline in the mean absolute monthly abnormal returns of firms in the highest accrual decile-from 78 basis points to 15 basis points, respectively.

This decline is accompanied by a rise in short arbitrage activity across the same subperiods. Panel B shows that the mean fifth-month short interest for firms in the highest accrual decile increased steadily from $1.36 \%$ in subperiod 1990-94 to $5.26 \%$ in subperiod 2005-09. These patterns suggest that investment professionals have recognized and acted upon the documentation of the accrual anomaly in academic studies. 
A Mean absolute monthly Abnormal Return in basis points for firms in the highest accruals decile

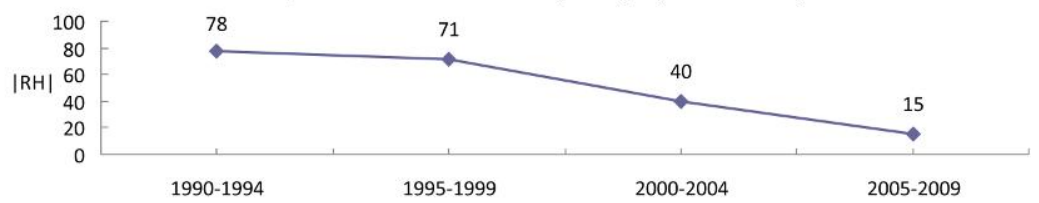

B

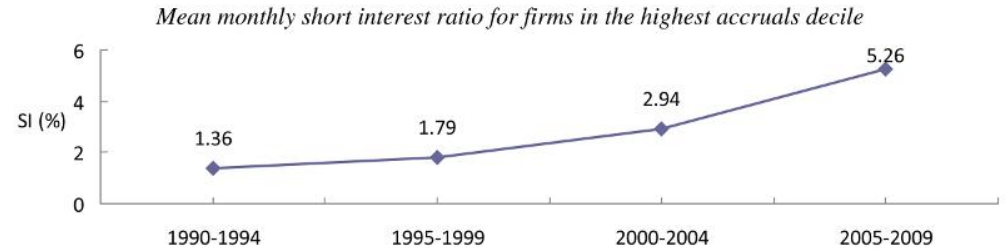

C
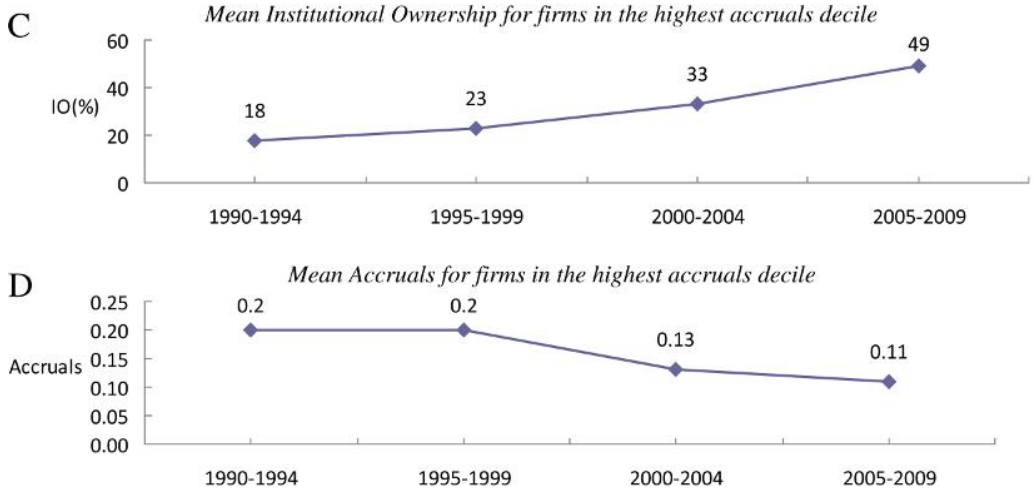

Figure 3

Time-series evolution of the accrual anomaly and short arbitrage activity

This figure examines the time-series evolution of short-side abnormal return of the accrual anomaly, short arbitrage activity (SI), institutional ownership (IO), and accruals over four consecutive 5-year periods from 1990-94 through 2005-09. Panel A uses the same methods of accruals portfolio formation and abnormal return calculation as detailed in Table 2. $\mathbf{R}_{\mathbf{H}}$ denotes the average abnormal return for the highest accruals decile portfolio. $\mathbf{R}_{\mathbf{H}}$ is negative for all four periods; we plot it in absolute values, expressed in basis points. Panels B through D use the same method of accruals portfolio formation as detailed in Table 4. See Table 1 notes for the definitions of Accruals, $I O$, and $S I$.

Figure 3, Panel C, suggests that this growth in short arbitrage activity may have been facilitated by the greater ease of short selling, as reflected in evidence of rapid growth in institutional ownership over these subperiods. The mean institutional ownership over time increased from $18 \%$ to $49 \%$ over these subperiods. The time trends of decreased trading profits, and increased short interest and institutional ownership, are highly statistically significant.

Panel D shows a statistically significant decline over time in the level of accruals within the top accrual decile, from 0.20 to 0.12 in the 1990 s versus the 2000s. A possible explanation is that either rising sophistication by investors about the prospects of high accrual firms or increased regulation and litigation risk may have reduced the strategic incentives for managers to manage accruals upward. 
Any weakening of managers' incentives to manage earnings would tend to reduce the overpricing associated with high accruals. Furthermore, the greater ease of short selling over time associated with increased institutional ownership, as well as increased short arbitrage associated with the rapid growth of hedge funds, may also have contributed to the weakening in the accrual anomaly. In sum, greater ease of arbitrage, greater understanding by arbitrageurs of the accrual anomaly, and a decrease in investor misperceptions all may have played a role in the apparent diminishing of the accrual anomaly over time.

\section{Short Arbitrage of the Accrual Anomaly: Multivariate Tests}

A disadvantage of a univariate analysis in changes in short interest in the earlier sections is that some of the cross-sectional differences in short interest are due to cross-sectional differences in accruals, the effects we would like to detect. More importantly, a univariate change analysis filters out only extraneous fixed effects, not time-varying effects.

Multivariate testing of whether there is short arbitrage of the accrual anomaly is important for two reasons. The first is that there are several determinants of short interest in general that need not derive from arbitrage of these anomalies. The second reason is that the accruals variable is correlated with other return predictors. In consequence, short arbitrage of one anomaly (e.g., momentum or book-to-market) could induce a correlation between short interest and accruals, even if no investor is basing a decision to go short on accruals. Thus, to verify short arbitrage of the accrual anomaly we need to control for other return predictors. For example, there is indeed evidence that short interest is correlated with firms' book-to-market ratios, suggesting that there is short arbitrage of the "value" (book-to-market) effect (Dechow, Hutton, Meulbroek, and Sloan 2001).

We therefore perform multivariate tests that explicitly control both for other determinants of short interest and for other known predictors of stock returns. This allows us to verify whether the apparent arbitrage of the accrual anomaly found in our univariate tests (both in levels and in changes) is actually due to arbitrageurs trading in response to accruals.

To control for other general determinants of short interest, we include in our regressions measures of institutional ownership, residual return volatility, book-to-market, size, momentum, leverage, liquidity, analyst following, a loss firm dummy, and a dummy variable for trading venue. When institutional ownership is high, the stock is easier to borrow for purposes of short selling (Asquith, Pathak, and Ritter 2005), so we control for institutional holdings $(I O)$. Higher liquidity also tends to make a stock easier to sell short, so we control for the log transformation of the Amihud illiquidity measure (InIlliquidity). High residual volatility can make short arbitrage riskier, so we include a residual volatility measure (STDRES) as a control (see Pontiff 1996; Duan, $\mathrm{Hu}$, and McLean 2009; Mashruwala, Rajgopal, and Shevlin 2006). 
A general propensity toward disagreement is another source of demand for shares to sell short (D'Avolio 2002). If high accruals happen to be associated with firms that have greater disagreement, this would induce an association between accruals and short interest even if no investors were selling short based upon the level of accruals. We therefore control for some general proxies for investor disagreement. High residual volatility may allow greater room for disagreement among investors, which provides a distinct interpretation of the residual volatility control. Similarly, we expect high uncertainty and therefore room for disagreement about firms with low analyst following and that are earning negative profits (LossFirm). Book-to-market (BTM) is an inverse proxy for disagreement if there is more disagreement about growth (low bookto-market) firms than about mature firms.

We also include a control for the trading venue, using a dummy variable NYSE, which is equal to 1 if the firm is NYSE-traded and 0 if it is a NASDAQ firm. Our proxies for liquidity and propensity to disagreement are imperfect, and the trading venue can offer additional relevant information. For example, Fishman, Hong, and Kubik (2010) discuss features of the trading institutions on the different exchanges which, ceteris paribus, make short selling easier on NASDAQ than on NYSE. In contrast, the kind of company that is able to qualify for, and chooses to be traded upon, the NYSE may have greater liquidity and a more transparent information environment.

When shares are easy to borrow, investors can take short positions against overvaluation that is driven by high accruals. Past literature has identified institutional holdings as a key indicator of the availability of shares for borrowing. We therefore predict that high institutional holdings should be associated with stronger short arbitrage. To test this prediction, we include interactions of $I O$ with accrual (in addition to including $I O$ as a main effect).

The book-to-market and size variables are useful as controls for a second reason: their documented ability to predict future returns. Since momentum is a strong stock return predictor, we also include a momentum variable, measured as the compounded past returns from months -12 to -2 relative to the short interest position month.

We saw in Section 4.1 that there was a nonlinear relationship in which short interest was concentrated especially in the top accrual decile, and that conceptually this makes sense because when there are fixed costs of short arbitrage, it is most profitable to focus on the most overvalued firms. (We also saw evidence in subsection 4.4 that moving into the top accrual decile was associated with an increase in short interest.) To capture the nonlinear nature of short arbitrage, in our multivariate tests we use a dummy variable, HighAccrual, that is equal to one when the firm's accruals are in the top decile, and zero otherwise.

Table 7 describes multivariate regressions of short interest on HighAccrual, as well as year fixed effects, control variables discussed above, and the interaction of HighAccrual with institutional ownership variables. The nonlinear effect of institutional ownership on the ease of short selling is allowed for in 
Table 7

Multivariate analysis of short interest levels

\begin{tabular}{|c|c|c|c|c|}
\hline IO measure: & $\begin{array}{l}\text { Model } 1 \\
\text { lnIO }\end{array}$ & $\begin{array}{c}\text { Model } 2 \\
\ln I O\end{array}$ & $\begin{array}{c}\text { Model } 3 \\
\text { LowIO }\end{array}$ & $\begin{array}{c}\text { Model } 4 \\
\text { Low_Resi_IO }\end{array}$ \\
\hline HighAccrual & $\begin{array}{l}0.9598^{* * *} \\
(10.18)\end{array}$ & $\begin{array}{l}0.2116^{* * *} \\
(2.38)\end{array}$ & $\begin{array}{l}1.0992 * * * \\
(10.04)\end{array}$ & $\begin{array}{l}0.9275^{* * * *} \\
(9.10)\end{array}$ \\
\hline$I O$ & $\begin{array}{l}8.7954 * * * \\
(5.56)\end{array}$ & $\begin{array}{l}8.4538 * * * \\
(5.29)\end{array}$ & $\begin{array}{l}-0.1858 * * * \\
(-2.68)\end{array}$ & $\begin{array}{l}-0.3829 * * * \\
(-3.77)\end{array}$ \\
\hline HighAccrual $* I O$ & & $\begin{array}{l}3.1036 * * * \\
(6.15)\end{array}$ & $\begin{array}{l}-1.0647 * * * \\
(-8.02)\end{array}$ & $\begin{array}{l}-0.6257 * * * \\
(-4.81)\end{array}$ \\
\hline InIlliquidity & $\begin{array}{l}-0.4510^{* * *} \\
(-9.71)\end{array}$ & $\begin{array}{l}-0.4528 * * * \\
(-9.75)\end{array}$ & $\begin{array}{l}-0.5882 * * * \\
(-7.44)\end{array}$ & $\begin{array}{l}-0.6009 * * * \\
(-7.34)\end{array}$ \\
\hline Leverage & $\begin{array}{l}0.4163 * * * \\
(3.16)\end{array}$ & $\begin{array}{l}0.4171 * * * \\
(3.16)\end{array}$ & $\begin{array}{l}0.3686 * * * \\
(2.98)\end{array}$ & $\begin{array}{l}0.3710 * * * \\
(3.01)\end{array}$ \\
\hline LossFirm & $\begin{array}{l}0.7521 * * * \\
(9.69)\end{array}$ & $\begin{array}{l}0.7469 * * * \\
(9.71)\end{array}$ & $\begin{array}{l}0.6430 * * * \\
(8.38)\end{array}$ & $\begin{array}{l}0.6428 * * * \\
(8.41)\end{array}$ \\
\hline STDRES & $\begin{array}{l}15.0668 * * * \\
(5.50)\end{array}$ & $\begin{array}{l}14.9484 * * * \\
(5.42)\end{array}$ & $\begin{array}{l}10.8220 * * * \\
(3.07)\end{array}$ & $\begin{array}{l}11.0102 * * * \\
(3.07)\end{array}$ \\
\hline InSize & $\begin{array}{l}0.0436 \\
(0.95)\end{array}$ & $\begin{array}{l}0.0448 \\
(0.98)\end{array}$ & $\begin{array}{l}0.3195 * * * \\
(5.69)\end{array}$ & $\begin{array}{l}0.3386 * * * \\
(5.89)\end{array}$ \\
\hline BTM & $\begin{array}{l}-0.0263 \\
(-1.62)\end{array}$ & $\begin{array}{l}-0.0265 \\
(-1.64)\end{array}$ & $\begin{array}{l}-0.0011 \\
(-0.10)\end{array}$ & $\begin{array}{l}-0.0005 \\
(-0.05)\end{array}$ \\
\hline Momentum & $\begin{array}{l}0.0095 \\
(0.12)\end{array}$ & $\begin{array}{l}0.0100 \\
(0.12)\end{array}$ & $\begin{array}{l}-0.0276 \\
(-0.24)\end{array}$ & $\begin{array}{l}-0.0290 \\
(-0.25)\end{array}$ \\
\hline $\ln A F$ & $\begin{array}{l}0.1211 \\
(1.48)\end{array}$ & $\begin{array}{l}0.1243 \\
(1.52)\end{array}$ & $\begin{array}{l}0.6591 * * * \\
(4.83)\end{array}$ & $\begin{array}{l}0.6427 * * * \\
(4.87)\end{array}$ \\
\hline NYSE & $\begin{array}{l}-0.9907 * * * \\
(-6.63)\end{array}$ & $\begin{array}{l}-0.9819 * * * \\
(-6.49)\end{array}$ & $\begin{array}{l}-0.9069 * * * \\
(-5.14)\end{array}$ & $\begin{array}{l}-0.9176 \text { **** } \\
(-5.15)\end{array}$ \\
\hline Constant & $\begin{array}{l}-1.1713 * * * \\
(-5.92)\end{array}$ & $\begin{array}{l}-1.0748^{* * * *} \\
(-5.33)\end{array}$ & $\begin{array}{l}-0.3473 \\
(-1.26)\end{array}$ & $\begin{array}{l}-0.4182 \\
(-1.59)\end{array}$ \\
\hline$N$ & 90,567 & 90,567 & 90,567 & 90,567 \\
\hline Adjusted $R^{2}$ & 0.217 & 0.219 & 0.129 & 0.128 \\
\hline
\end{tabular}

(continued)

alternative specifications similar to Table 3. To test for significance, $t$-statistics are based on Thompson (2010) two-way clustered standard errors (clustering by both firm and month) in Panel A. The results from a Fama-MacBeth panel regression approach with a Newey-West adjustment for standard errors are in Panel B. Since they are qualitatively similar to Panel A, we discuss only the Panel A results. ${ }^{17}$

Table 7 provides strong evidence of short arbitrage of the accrual anomaly, and that this activity is stronger when shares are more readily available to borrow. These tests control for other predictors of stock returns and determinants of short interest. The base Model 1 does not include any interaction between HighAccrual and institutional ownership. The highly significant coefficient $(t=10.18)$ on HighAccrual indicates that it is incrementally associated with greater short interest. Holding constant all other variables, the average effect of a firm being within the top accrual decile is an increase in short interest of $0.96 \%$. As benchmarks for comparison, the mean (median) short interest in the sample is $2.20 \%(0.52 \%)$. Thus, the effect of accruals on short interest is economically substantial.

17 The conclusions are also robust to omitting stocks with price less than $\$ 5$. 
Table 7

Continued

Panel B: Fama-MacBeth regressions

\begin{tabular}{|c|c|c|c|c|}
\hline IO measure: & $\begin{array}{c}\text { Model } 1 \\
\ln I O\end{array}$ & $\begin{array}{c}\text { Model } 2 \\
\operatorname{lnIO}\end{array}$ & $\begin{array}{c}\text { Model } 3 \\
\text { LowIO }\end{array}$ & $\begin{array}{c}\text { Model } 4 \\
\text { Low_Resi_IO }\end{array}$ \\
\hline High Accrual & $\begin{array}{l}0.8423 * * * \\
(6.99)\end{array}$ & $\begin{array}{l}0.1462 \\
(1.28)\end{array}$ & $\begin{array}{l}0.9356 \text { *** } \\
(9.33)\end{array}$ & $\begin{array}{l}0.8378 * * * \\
(7.46)\end{array}$ \\
\hline$I O$ & $\begin{array}{l}5.7594 * * * \\
(2.83)\end{array}$ & $\begin{array}{l}5.4609 * * \\
(2.68)\end{array}$ & $\begin{array}{l}-0.3158 \\
(-1.84)\end{array}$ & $\begin{array}{l}-0.6230 * * \\
(-2.49)\end{array}$ \\
\hline HighAccrual $* I O$ & & $\begin{array}{l}2.8097 \text { *** } \\
(5.72)\end{array}$ & $\begin{array}{l}-0.7433 \text { *** } \\
(-5.42)\end{array}$ & $\begin{array}{l}-0.4790 * * * \\
(-3.08)\end{array}$ \\
\hline InIlliquidity & $\begin{array}{l}-0.7079 \text { *** } \\
(-5.01)\end{array}$ & $\begin{array}{l}-0.7058 * * * \\
(-5.05)\end{array}$ & $\begin{array}{l}-0.9222 * * * \\
(-3.75)\end{array}$ & $\begin{array}{l}-0.9562 * * * \\
(-3.61)\end{array}$ \\
\hline Leverage & $\begin{array}{l}0.6575^{* * * *} \\
(4.76)\end{array}$ & $\begin{array}{l}0.6614 * * * \\
(4.78)\end{array}$ & $\begin{array}{l}0.6422 \text { *** } \\
(4.35)\end{array}$ & $\begin{array}{l}0.6742 * * * \\
(4.24)\end{array}$ \\
\hline LossFirm & $\begin{array}{l}0.3376^{* * * *} \\
(3.58)\end{array}$ & $\begin{array}{l}0.3325^{* * * *} \\
(3.55)\end{array}$ & $\begin{array}{l}0.2349 * * \\
(2.26)\end{array}$ & $\begin{array}{l}0.2395 * * \\
(2.30)\end{array}$ \\
\hline STDRES & $\begin{array}{l}27.2253^{* * * *} \\
(3.24)\end{array}$ & $\begin{array}{l}27.1513^{* * * *} \\
(3.22)\end{array}$ & $\begin{array}{l}20.1825^{* * * *} \\
(4.31)\end{array}$ & $\begin{array}{l}20.3887 * * * \\
(4.47)\end{array}$ \\
\hline lnSize & $\begin{array}{l}-0.1361 \\
(-1.54)\end{array}$ & $\begin{array}{l}-0.1350 \\
(-1.51)\end{array}$ & $\begin{array}{l}-0.0886 \\
(-1.02)\end{array}$ & $\begin{array}{l}-0.0654 \\
(-0.83)\end{array}$ \\
\hline BTM & $\begin{array}{l}-0.0212^{* *} \\
(-2.19)\end{array}$ & $\begin{array}{l}-0.0212^{* *} \\
(-2.25)\end{array}$ & $\begin{array}{l}0.0121 \\
(0.57)\end{array}$ & $\begin{array}{l}0.0053 \\
(0.28)\end{array}$ \\
\hline Momentum & $\begin{array}{l}0.2492 * * * \\
(4.19)\end{array}$ & $\begin{array}{l}0.2478 * * * \\
(4.16)\end{array}$ & $\begin{array}{l}0.2904 * * * \\
(4.44)\end{array}$ & $\begin{array}{l}0.3032 * * * \\
(4.51)\end{array}$ \\
\hline $\ln A F$ & $\begin{array}{l}0.5531 \text { *** } \\
(4.22)\end{array}$ & $\begin{array}{l}0.5563 \text { *** } \\
(4.20)\end{array}$ & $\begin{array}{l}1.0221 * * * \\
(3.32)\end{array}$ & $\begin{array}{l}0.9802 * * * \\
(3.41)\end{array}$ \\
\hline NYSE & $\begin{array}{l}-0.4290 \text { *** } \\
(-3.85)\end{array}$ & $\begin{array}{l}-0.4200 * * * \\
(-3.79)\end{array}$ & $\begin{array}{l}-0.2584 * * * \\
(-3.00)\end{array}$ & $\begin{array}{l}-0.2715 * * * \\
(-3.08)\end{array}$ \\
\hline Constant & $\begin{array}{l}-0.5299 \\
(-1.63)\end{array}$ & $\begin{array}{l}-0.4465 \\
(-1.44)\end{array}$ & $\begin{array}{l}1.0394 \\
(1.73)\end{array}$ & $\begin{array}{l}0.9983 \\
(1.69)\end{array}$ \\
\hline Adjusted $R^{2}$ & 0.166 & 0.169 & 0.123 & 0.169 \\
\hline
\end{tabular}

The dependent variable is short interest ratio (SI), calculated as the short position in the fifth month after the fiscal year-end divided by the number of shares outstanding on the same date (15th of each month or the preceding business day if the 15th is not a business day) as reported on the CRSP daily stock file, then multiplied by 100 to express as a percentage. Sample observations are sorted into accrual deciles each year. HighAccrual is a dummy variable taking the value of 1 if the firm-year ranks among the highest accruals decile, 0 otherwise. $\operatorname{lnIO}$ is the log transformation of institutional ownership (IO). LowIO is defined as a dummy variable taking the value of 1 if IO is less than 5\%,0 otherwise. Low_Resi_IO is defined as a dummy variable taking the value of 1 if the firm's Resi_IO ranks among the lowest RESI_IO (residual institutional ownership) decile for the year, 0 otherwise. InSize is the logarithm of $1+$ Size. InIlliquidity is the logarithm of (Illiquidity +1$) \cdot \ln A F$ is the logarithm of $1+A F$. NYSE is a dummy variable equal to 1 if the firm is listed on NYSE, 0 if listed on NASDAQ. Table 1 notes define all other variables. In Panel A, the $t$-statistics reported in parentheses are computed based on Thompson (2010) two-way clustered standard errors (clustering by both firm and month) correcting for crosssectional and time-series dependence. In Panel B, cross-sectional regressions are run by year and the time-series averages of regression coefficients are reported, with Newey-West adjustment for standard errors. ** and *** denote statistical significance at the $5 \%$ and $1 \%$ levels, respectively.

The Model 2 findings, which include an interaction variable between high accruals decile indicator and institutional ownership, further indicate that greater ease of short selling, as proxied by institutional ownership, causes greater short arbitrage of the accrual anomaly. The use of institutional ownership as an instrument helps allay concern that the relation between accruals and short interest is driven by omitted variables rather than arbitrage activity. The coefficient on HighAccrual* $\ln I O$ is a highly significant $3.1036(t=6.15)$, implying that as the constraint on loanable shares is relaxed, there is an increase in short selling targeting toward high accrual firms. The effect of HighAccrual 
on short interest is significantly greater when institutional shareholding is high. If the accrual anomaly represented a rational risk premium, there would be no rational reason for short sellers to systematically target high accrual firms, and no reason for constraints on short selling to affect return asymmetry. ${ }^{18}$ This finding therefore further confirms the interpretation of the accrual anomaly as representing a market inefficiency.

Models 3 and 4 generate similar findings. Short arbitrage of the accrual anomaly remains very pronounced when there is sufficient amount of institutional ownership, but becomes significantly weaker among firms where the institutional ownership drops below 5\%, or when firms rank among the lowest residual institutional ownership decile.

As a further sensitivity analysis, in Table 8 we regress the change in short interest on the change in HighAccrual, and the changes in each of the controls. We remove interaction terms, because the change in Accruals * IO (where $I O$ is one of our institutional ownership proxies) from $t$ to $t+1$ includes levels, not just changes, in $I O$ and Accruals. This would leave firm fixed effects in the regression, which defeats the purpose of running a regression in changes. Change in HighAccrual remains a significant incremental predictor of changes in short interest. This evidence indicates that the evidence of short arbitrage of the accrual anomaly that we have identified is not just cross-sectional; it is present even in a pure time-series test.

Taken together, the findings of Sections 3-5 indicate that, in contrast with some previous literature, there is short arbitrage of the accrual anomaly. Firms with high accruals tend to have high short interest. Further confirming that this association comes from short arbitrage, the effect is stronger among stocks that, owing to high institutional holdings, are easier to borrow.

\section{Conclusions}

There is an active policy debate about whether short selling is in large part a means of manipulating stock prices, or whether it has a valuable economic function. Proponents of mild regulation of short selling argue that short arbitrage is crucial for preventing firms from becoming highly overvalued. In this article, we test whether short selling is targeted at firms that are overvalued owing to high accruals, and whether short arbitrage is effective in reducing overvaluation.

In order to focus on the effects of short arbitrage on return asymmetry, we use institutional shareholdings as an instrument for availability of loanable shares and, so, ease of short selling. We find that return asymmetry is greater for firms with low institutional holdings, as well as for illiquid firms (for which

18 It is, however, possible that short sellers irrationally target high accrual firms in the mistaken belief that they will underperform. A weakness of the conjecture that short sellers are largely irrational is that, as discussed in note 7 , several studies have found that in several contexts short selling negatively predicts returns or is associated with superior abnormal performance. 
Table 8

Multivariate analysis of short interest changes

\begin{tabular}{|c|c|}
\hline Variable & $\begin{array}{l}\text { Coefficient } \\
(t \text {-statistic) }\end{array}$ \\
\hline$\Delta$ HighAccrual & $\begin{array}{l}0.1406 * * \\
(2.51)\end{array}$ \\
\hline$\Delta \ln I O$ & $\begin{array}{l}9.7552 * * * \\
(6.30)\end{array}$ \\
\hline$\Delta$ InIlliquidity & $\begin{array}{l}-0.0983 \\
(-0.80)\end{array}$ \\
\hline$\Delta$ Leverage & $\begin{array}{l}0.3190 * * \\
(2.56)\end{array}$ \\
\hline$\Delta$ LossFirm & $\begin{array}{l}0.0055 \\
(0.12)\end{array}$ \\
\hline$\triangle S T D R E S$ & $\begin{array}{l}3.7965 \\
(1.15)\end{array}$ \\
\hline$\Delta \operatorname{lnSize}$ & $\begin{array}{l}0.2698 \\
(1.82)\end{array}$ \\
\hline$\triangle B T M$ & $\begin{array}{l}0.0154 \\
(1.31)\end{array}$ \\
\hline$\Delta$ Momentum & $\begin{array}{l}-0.1120 * * \\
(-2.21)\end{array}$ \\
\hline$\triangle \ln A F$ & $\begin{array}{l}0.3323 \text { *** } \\
(8.28)\end{array}$ \\
\hline Constant & $\begin{array}{l}0.0529 \\
(0.45)\end{array}$ \\
\hline $\begin{array}{l}N \\
\text { Adjusted } R^{2}\end{array}$ & $\begin{array}{r}78,330 \\
0.068\end{array}$ \\
\hline
\end{tabular}

The dependent variable is the change in short interest level $(\Delta S I)$, calculated as the short interest ratio for the firm-year (measured as of the fifth month after the fiscal year-end) minus the short interest ratio for the same firm a year ago. For example, if the accrual is measured as of December 1995 (fiscal year-end), then the corresponding change in short interest is calculated as the difference between the short interest ratio as of May 1996 and the short interest ratio as of May 1995. AHighAccrual is the annual change in the HighAccrual dummy variable. For example, if the firm ranks among the highest accrual decile at year $t-1$, but is no longer so at year $t$, then $\Delta$ HighAccrual takes the value of -1 for year $t$; if the firm does not rank among the highest accrual decile at year $t-1$, but becomes so at year $t$, then $\Delta$ HighAccrual takes the value of +1 for year $t$; otherwise, $\Delta$ HighAccrual takes the value of 0 . The three institutional ownership (IO) measures, InIO, LowIO, and Low_Resi_IO, are defined the same way as in Table 7. $\Delta$ lnIlliquidity, $\Delta$ Leverage, $\Delta$ LossFirm, $\triangle$ STDRES, $\triangle \operatorname{lnSize,~} \triangle B T M, \triangle M o m e n t u m$, $\Delta \ln A F$, and $\Delta \operatorname{lnIO}$ are similarly measured as the changes in the corresponding variables from year $t-1$ to year $t$, respectively. The $t$-statistics reported in parentheses are computed based on Thompson (2010) two-way clustered standard errors (clustering by both firm and month) correcting for cross-sectional and time-series dependence. $* *$ and $* * *$ denote statistical significance at the $5 \%$ and $1 \%$ levels, respectively.

short sellers are at greater risk for short squeezes), and on NASDAQ rather than NYSE (probably because of selection onto NASDAQ of firms that are subject to greater extremes of mispricing and risks of selling short). We confirm the importance of constraints on short arbitrage for return asymmetry after extensive controls for other possible determinants, such as size, book-to-market, residual standard deviation, analyst following, leverage, and whether the firm is earning negative profits.

We find, in sharp contrast with the findings of Richardson (2003) in a smaller sample, that short arbitrageurs target high accrual firms during the 1988-2009 period. Furthermore, in years when a firm moves into the top accrual decile, short interest on average increases by a highly significant and substantial economic magnitude. 
We use extensive controls for determinants of short interest; and for other known return predictors, such as 12-month return momentum, to evaluate the incremental short-selling activity specifically associated with the accrual anomaly. In multivariate tests that include these controls, there is highly significant evidence of short arbitrage of the accrual anomaly. To test whether the relation between accruals and short selling is causal, we examine whether greater ease of borrowing stock affects the extent of short arbitrage. We document a strong interaction effect; short arbitrage is much stronger in firms held heavily by institutions (for which shares are more readily available for borrowing).

In both univariate and multivariate tests, we find that short arbitrage targeted at the highest accrual decile of firms is greater on NASDAQ than on NYSE, though the amount of short interest per unit of accrual is lower. Return asymmetry is present only on NASDAQ.

Overall, the evidence in this article paints a picture in which short selling has only a degree of success in eliminating the downside of the accrual anomalies. There is strong evidence that short sellers bet against high accrual firms. But asymmetry in the accrual anomaly remains, and this asymmetry is greater for firms with low institutional holdings (for which shares are hard to borrow for short selling), for less liquid firms, and on NASDAQ rather than NYSE.

There is a general debate in the accounting and asset pricing literatures about whether anomalies represent market inefficiencies, rational risk premia, or some form of data snooping or measurement error. Our findings, that there is short arbitrage of the accrual anomaly, but that there is asymmetry in return predictability that increases with constraints on short arbitrage, provide a new and distinct form of evidence that the accrual anomaly does indeed represent a market inefficiency. We also find that the accrual anomaly has declined in strength over time. A possible explanation is the greater ease in short selling against high accrual firms associated with rising levels of institutional ownership, which makes it easier to borrow shares. Another is the rapid increase in hedge fund trading over the sample period. Both factors suggest that greater activity by short sellers has played a role in at least partially correcting this market inefficiency.

As a policy matter, our findings suggest that trading venues or regulatory policies that allow short selling to be cheaper and less risky can improve market efficiency. Contrasting examples are the relaxation by the Securities and Exchange Commission of the uptick rule restricting short sales (Diether, Lee, and Werner 2009a; Jakab 2008) and recent efforts to constrain short selling described in note 1 . Greater ease of short selling may potentially help protect investors from the hazards of trading overpriced stocks.

\section{References}

Ali, A., and M. A. Trombley. 2006. Short Sales Constraints and Momentum in Stock Returns. Journal of Business, Finance, and Accounting 33:587-615. 
Amihud, Y. 2002. Illiquidity and Stock Returns: Cross-section and Time-series Effects. Journal of Financial Markets 5:31-56.

Asquith, P., P. Pathak, and J. Ritter. 2005. Short Interest, Institutional Ownership, and Stock Returns. Journal of Financial Economics 78:243-76.

Boehmer, E., C. Jones, and X. Zhang. 2008. Which Shorts Are Informed? Journal of Finance 63: 491-527.

Boehmer, E., C. Jordan, and Z. Huszar. 2010. The Good News in Short Interest. Journal of Financial Economics 96:80-97.

Bradshaw, M. T., S. A. Richardson, and R. G. Sloan. 2001. Do Analysts and Auditors Use the Information in Accruals? Journal of Accounting Research (June):35-74.

Bris, A., W. Goetzmann, and N. Zhu. 2007. Efficiency and the Bear: Short Sales and Markets around the World. Journal of Finance 62:1029-79.

Cao, B., D. Dhaliwal, A. Kolasinski, and A. Reed. 2007. Bears and Numbers: Investigating How Short Sellers Exploit and Affect Earnings-based Pricing Anomalies. Working Paper, University of Washington.

Cohen, L., K. Diether, and C. Malloy. 2007. Supply and Demand Shifts in the Shorting Market. Journal of Finance 62:2061-96.

Daniel, K., M. Grinblatt, S. Titman, and R. Wermers. 1997. Measuring Mutual Fund Performance with Characteristic-based Benchmarks. Journal of Finance 52:1035-58.

Daniel, K., and S. Titman. 1997. Evidence on the Characteristics of Cross-sectional Variation in Stock Returns. Journal of Finance 52:1-33.

D’Avolio, G. 2002. The Market for Borrowing Stock. Journal of Financial Economics 66:271-306.

Dechow, P. M., A. P. Hutton, L. Meulbroek, and R. G. Sloan. 2001. Short Sellers, Fundamental Analysis, and Stock Returns. Journal of Financial Economics 61:77-106.

Desai, H., S. Krishnamurthy, and K. Venkataraman. 2006. Do Short Sellers Target Firms with Poor Earnings Quality? Evidence from Earnings Restatements. Review of Accounting Studies 11:71-90.

Desai, H., K. Ramesh, S. Thiagarajan, and B. Balachandran. 2002. An Investigation of the Information Role of Short Interest in the NASDAQ Market. Journal of Finance 52:2263-87.

Diether, K., K. H. Lee, and I. Werner. 2009a. It's SHO Time! Short-sale Price Tests and Market Quality. Journal of Finance 64:37-73.

2009b. Short-sale Strategies and Return Predictability. Review of Financial Studies 22:575-607.

Diether, K., and I. Werner. 2010. When Constraints Bind. Working Paper, Ohio State University.

Drake, M. S., and L. A. Myers. 2011. Analysts' Accrual-related Over-optimism: Do Analyst Characteristics Play a Role? Review of Accounting Studies 16:59-88.

Duan, Y., G. Hu, and R. McLean. 2009. Costly Arbitrage and Idiosyncratic Risk: Evidence from Short Sellers. Journal of Financial Intermediation 19:564-79.

Fairfield, P., J. Whisenant, and T. Yohn. 2003. Accrued Earnings and Growth: Implications for Future Profitability and Market Mispricing. Accounting Review 78:353-71.

Fama, E., and K. French. 1993. Common Risk Factors in the Returns on Stocks and Bonds. Journal of Financial Economics 33:3-56.

Paper No. 610 .

2010. Dissecting Anomalies. University of Chicago, Graduate School of Business, CRSP Working

Fishman, T., H. Hong, and J. Kubik. 2010. Do Arbitrageurs Amplify Economic Shocks? Working Paper, Princeton University. 
Greenwood, R. 2009. Trading Restrictions and Stock Prices. Review of Financial Studies 22:509-39.

Griffin, J., and M. Lemmon. 2002. Does Book-to-market Equity Proxy for Distress Risk? Journal of Finance 57:2317-36.

Hirshleifer, D., K. Hou, and S. H. Teoh. 2011. The Accrual Anomaly: Risk or Mispricing? Management Science. Advance Access published Februrary 15, 2011, 10.1287/mnsc.1100.1289.

Hirshleifer, D., K. Hou, S. H. Teoh, and Y. Zhang. 2004. Do Investors Overvalue Firms with Bloated Balance Sheets? Journal of Accounting and Economics 38:297-331.

Hribar, P., and D. Collins. 2002. Errors in Estimating Accruals, Implications for Empirical Research. Journal of Accounting Research 40:105-34.

Jakab, S. 2008. Short-sellers May Owe ETFs Some Thanks: Dropping of "Uptick" Rule by SEC Comes as Growth of Stock Baskets Is Soaring. Wall Street Journal (June 15):C11.

Jones, C., and O. Lamont. 2002. Short-sale Constraints and Stock Returns. Journal of Financial Economics $66: 207-39$

Lamont, O., and R. Thaler. 2003. Can the Market Add and Subtract? Mispricing in Tech Stock Carve-outs. Journal of Political Economy 111:227-68.

Mashruwala, C., S. Rajgopal, and T. Shevlin. 2006. Why Is the Accrual Anomaly Not Arbitraged Away? Journal of Accounting and Economics 42:3-33.

Nagel, S. 2005. Short Sales, Institutional Investors, and the Cross-section of Stock Returns. Journal of Financial Economics 78:277-309.

Ofek, E., M. Richardson, and R. Whitelaw. 2004. Limited Arbitrage and Short-sales Restrictions: Evidence from the Options Markets. Journal of Financial Economics 74:305-42.

Petersen, M. A. 2009. Estimating Standard Errors in Finance Panel Datasets: Comparing Approaches. Review of Financial Studies 22:435-80.

Polk, C., and P. Sapienza. 2009. The Stock Market and Corporate Investment: A Test of Catering Theory. Review of Financial Studies 22:187-217.

Pontiff, J. 1996. Costly Arbitrage: Evidence from Closed-end Funds. Quarterly Journal of Economics 111:1135-51.

Richardson, S. 2003. Earnings Quality and Short Sellers. Accounting Horizons 17 (Supplement):49-61.

Richardson, S., R. Sloan, M. Soliman, and I. Tuna. 2005. Accrual Reliability, Earnings Persistence, and Stock Prices. Journal of Accounting and Economics 39:437-85.

Shumway, T. 1997. The Delisting Bias in CRSP Data. Journal of Finance 52:327-40.

Sloan, R. 1996. Do Stock Prices Fully Reflect Information in Accruals and Cash Flows about Future Earnings? Accounting Review 71:289-315.

Teoh, S., I. Welch, and T. Wong. 1998a. Earnings Management and the Long-run Market Performance of the Initial Public Offering. Journal of Finance 53:1935-74.

1998b. Earnings Management and the Underperformance of Seasoned Equity Offerings. Journal of Financial Economics 51:63-99.

Teoh, S., and T. Wong. 2002. Why New Issue and High-accrual Firms Underperform: The Role of Analysts' Credulity. Review of Financial Studies 15:869-900.

Thompson, S. 2010. Simple Formulas for Standard Errors That Cluster by Both Firm and Time. Journal of Financial Economics 99:1-10. 